\title{
Los frescos góticos lineales de la iglesia de Sant Valentí de les Cabanyes (Barcelona)
}

\author{
Maria Gracia Salvà Pico
}

\section{INTRODUCCIÓN}

La pequeña iglesia de Sant Valentí se halla en el término municipal de Les Cabanyes, muy cerca de Vilafranca del Penedes (Barcelona). El mal estado en que se encontraba el edificio requeria una inmediata restauración, de la que se hizo cargo el Servicio de Patrimonio Arquitectónico de la Diputación de Barcelona. Siguiendo la norma de dicho Servicio, antes de la intervención arquitectónica se llevó a cabo una exhaustiva investigación histórica (dirigida por el doctor Alberto López Mullor) que comprendió una excavación arqueológica, un estudio documental y un análisis artístico. A nosotros nos correspondió el estudio de las pinturas murales que cubrian buena parte del templo.

Estos frescos fueron descubiertos el año 1973. Durante el verano de 1980, se llevó a cabo una primera y única restauración, realizada por los alumnos del curso de restauración de pintura mural celebrado en Sant Cugat del Vallès (Barcelona). La campaña consistió en la consolidación y fijación de los murales bajo la dirección del señor Josep M. Xarrié (1981: 318).

En el año 1981, se publicaron dos estudios sobre este conjunto mural. En el primero (Ibidem 1981: 318-320) las pinturas se agrupan en cinco paneles sin determinarse su situación exacta, se hace un análisis formal, una interpretación iconográfica (que en algunos casos es inexacta) y se les da una cronologia amplia, fijada entre los siglos xII y xIV. El segundo (SuREDA 1981: 364-381), mucho más extenso y profundo que el anterior, se basa en el estudio del señor Xarrié, aunque introduce innovaciones importantes: unifica las escenas en cinco zonas y las sitúa topográfica- 
mente, propone una interpretación iconográfica que creemos acertada (aunque en algunos casos planteamos identificaciones diferentes), siendo plenamente aceptables el análisis formal y la filiación estilistica. Por lo que se refiere a la cronología este autor cree que el conjunto pictórico es unitario, ejecutado hacia 1350-1360, ello, como veremos, difiere un tanto de nuestras apreciaciones.

\section{DESCRIPCIÓN}

Buena parte de la decoración mural ha desaparecido y la que se conserva está muy fragmentada. Por ambos motivos la lectura del conjunto es difícil y necesariamente ha de quedar incompleta debido a la falta de imágenes. Para hacer más comprensible el argumento, formulamos una descripción lineal de las escenas, aunque no siga el mismo orden que el discurso iconográfico. Debido a razones topográficas, iconográficas y cronológicas, hemos distribuido los frescos en dos sectores: las pinturas de poniente y las pinturas del nordeste (fig. 1).

\section{Las pinturas de poniente}

Se concentran en tres zonas: la parte más occidental del muro sur de la nave, un sector del oeste y un fragmento del lado de poniente de la pared norte. En el paramento sur y de izquierda a derecha (figs. 2, 3), hay una serie de escenas en forma de friso continuo. Los primeros elementos son los que se aprecian con mayor dificultad, no obstante, hemos podido distinguir una caldera de color negro, de cuyo interior salen, como mínimo, tres cabezas humanas de largas cabelleras castañas y rubias. En el mismo eje de la caldera, un poco más arriba y desplazado hacia la izquierda, emerge el rostro de un personaje. A continuación, aparece una figura rara, de color marrón y perfilada con una gruesa línea negra. Presenta el aspecto de un animal, semejante a un enorme perro o lobo, con orejas cortas y puntiagudas, y gran nariz redondeada; de la boca entreabierta sobresalen dos hileras de dientes blancos. En un principio debía ser de cuerpo entero, ahora le falta un trozo considerable, y sólo se percibe la cabeza y los dos brazos. Esta figura demoníaca está de perfil, girada hacia la derecha, en dirección a la siguiente escena. Tiene levantado el brazo derecho y parece llevarse algo a la boca, con el otro brazo, sostiene un bastón largo acabado en tres puntas. En el lado izquierdo de la cabeza de este demonio, se ha conservado un pequeño fragmento de 


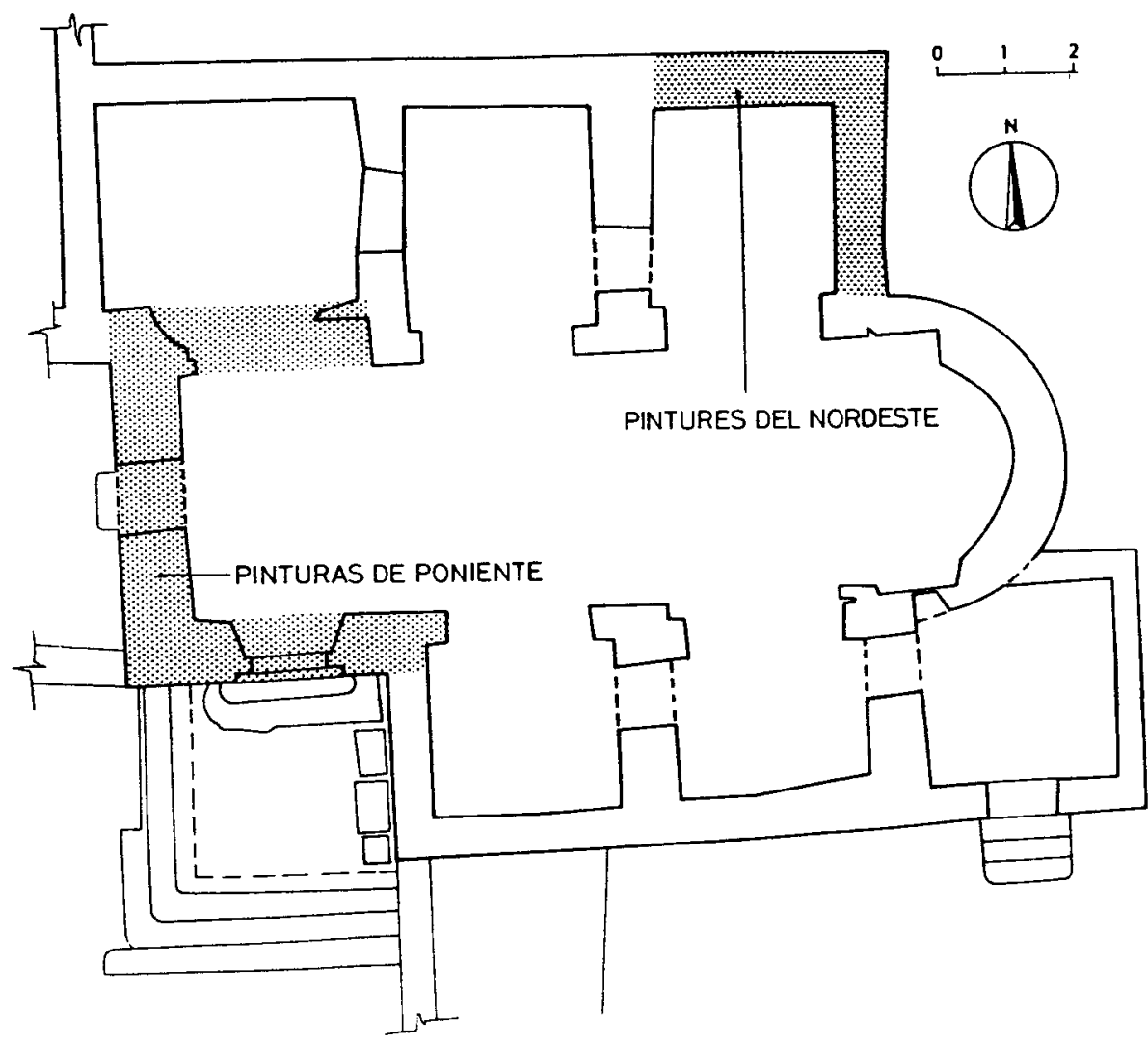

Fig. 1. Plano de la situación topográfica de las pinturas. La división del conjunto mural en dos zonas se justifica por su situación fisica y por razones formales, iconográficas y cronológicas

pintura con cuatro cabecitas, tal vez femeninas ya que tienen los cabellos largos.

El diablo descrito lleva un instrumento de tortura, de cuyo límite superior cuelga por el cuello, mediante un lazo, una figura humana desnuda. Este personaje es uno de los mejores conservados y aprovecharemos para describirlo más minuciosamente. Está configurado por una línea marrón bastante gruesa, que al mismo tiempo sirve para determinar sus rasgos anatómicos principales: rostro, cuello, pechos, costillas y ombligo. Resulta interesante destacar cómo se trazaron los pechos, mediante dos círculos abiertos por arriba. También es característica la forma de esbozar las costillas a partir de líneas curvas concéntricas. El ombligo tiene 


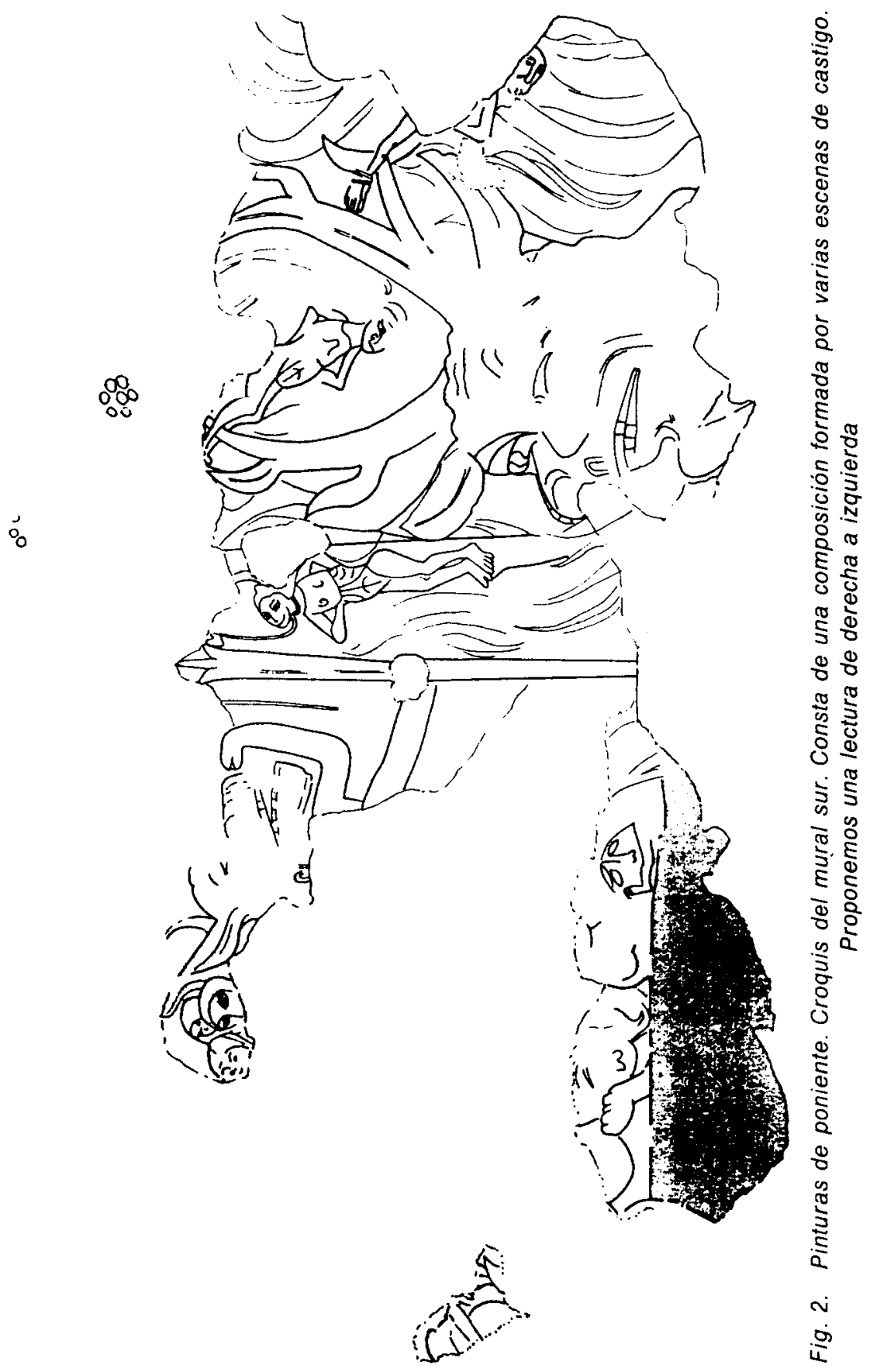




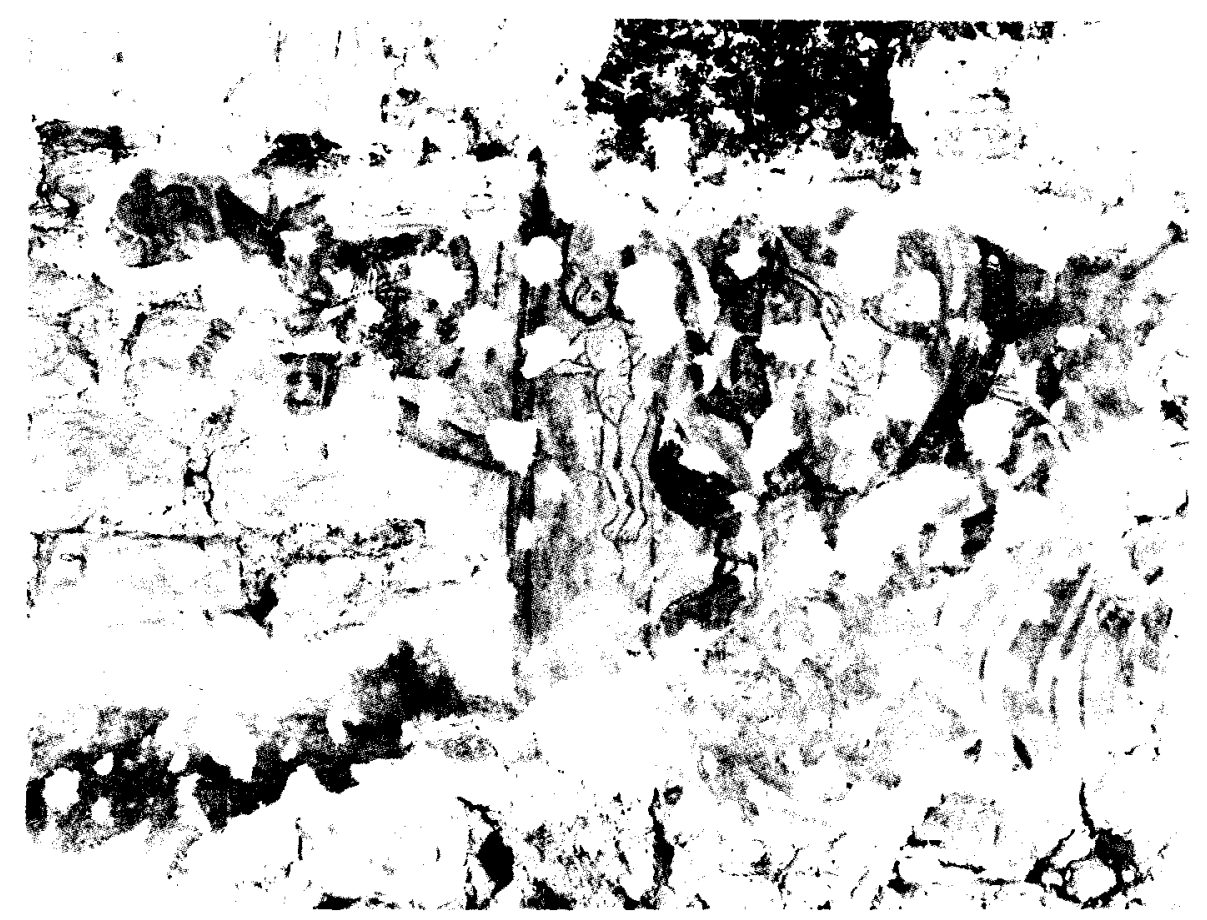

Fig. 3. Pinturas de poniente. Detalle de la composición del muro sur. Diversas penas de purgación: los condenados son atacados por los demonios, quemados y cocidos en una caldera

forma de cruz (con el brazo transversal flexionado), la boca es simplemente una linea curva, la nariz y la ceja derecha están unidas, en cambio la ceja izquierda es más pequeña y arqueada. Los ojos son prácticamente triangulares, con un punto negro en el centro que reproduce la pupila. Estos trazos dan forma al cuerpo, de tal manera que apenas está policromado, pues el color beige interno es el mismo que se ha utilizado para decorar los fondos de las escenas, únicamente los cabellos tienen un tono marrón rojizo. El condenado, con los ojos abiertos y la boca cerrada, está en posición de tres cuartos con la cabeza girada hacia la derecha y girado un poco hacia atrás. Tiene los dos brazos atados a la espalda a la altura de la cintura. El resto de las figuras presentan las mismas caracteristicas formales, únicamente cambian las posturas.

A continuación podemos observar una enorme cabeza de animal humanizada. Está perfilada con una línea negra, que enmarca una tinta plana marrón. El rostro aparece configurado por una gran boca, con dos hileras de dientes blancos, una nariz redondeada y voluminosa, grandes 
ojos abiertos, y orejas puntiagudas. De la parte superior de la cabeza le salen dos cuernas ramificadas, semejantes a las de los ciervos. Este demonio también está situado de tres cuartos, en este caso girado hacia la izquierda. De la cuerna de ese mismo lado, cuelga una figura atada por los pies, con la cabeza hacia abajo, y lanzada en el espacio creado entre la cornamenta. De la primera de las ramificaciones de la cuerna derecha cuelga, por los pies otro individuo, del que únicamente se advierten las extremidades inferiores, un brazo y parte de la cabeza. El fondo de esta composición está cubierto de líneas y franjas sinuosas de color rojo y marrón, que imitan las llamas.

Las escenas que ocupan la pared occidental de la iglesia (concentradas en la zona inferior izquierda), son las que ofrecen un estado más deficiente, y de las que sólo queda una tercera parte (figs. 4, 5). Además, esta composición fue mutilada cuando, en época moderna y contemporánea, se abrieron respectivamente un óculo y una puerta (LOPEZ, FIERRo, Clua 1991: 92-95). Empezaremos la descripción de izquierda a derecha. En primer lugar, hay una figura masculina desnuda, de cánon alargado. El tratamiento anatómico no es tan geométrico como el de los personajes descritos más arriba: los pechos consisten en unas lineas finas y onduladas, el ombiigo sólo es un punto, las costillas no se marcan; el rostro es más redondeado, la boca queda configurada por unos labios carnosos, la nariz es recta unida a la ceja derecha y los pómulos son dos puntos marrones. Presenta una posición de tres cuartos, parece que camina y que se dirige hacia la derecha. Con la mano izquierda sostiene un báculo acabado en cruz y mientras tanto levanta el brazo y la mano derechos. Un poco más arriba, encima de la cruz, hay otra criatura sin vestir de la que simplemente se conservan vestigios de la parte inferior del cuerpo. Aparenta estar flotando en el espacio. Al lado de la figura que lleva la cruz hay otra con un brazo detrás de la cintura, que está subiendo.

En la siguiente escena hay un árbol de color amarillo sin hojas, de cuyo tronco surgen simétricamente las ramas. No se ha preservado entero, pero es de suponer que era de grandes dimensiones. Flanqueando el tronco aparecen tres figuras. Una de ellas se sitúa a la derecha de éste: aparece desnuda, con cabellera rubia, el cuerpo un tanto flexionado, y los dos brazos juntos y levantados. Parece que salga disparada con cierta violencia. Las dos almas restantes están al otro lado del tronco, ambas están desnudas y son rubias. La de más hacia la derecha da una voltereta y la otra tiene la cabeza hacia abajo y roza una de las ramas con el pie. Los tres personajes se dirigen hacia la zona izquierda. Una última figura aparece situada encima de la segunda rama de la izquierda. Al lado de esta composición hay una laguna pictórica que no permite establecer la unión entre esta composición y la siguiente. Pensamos que 


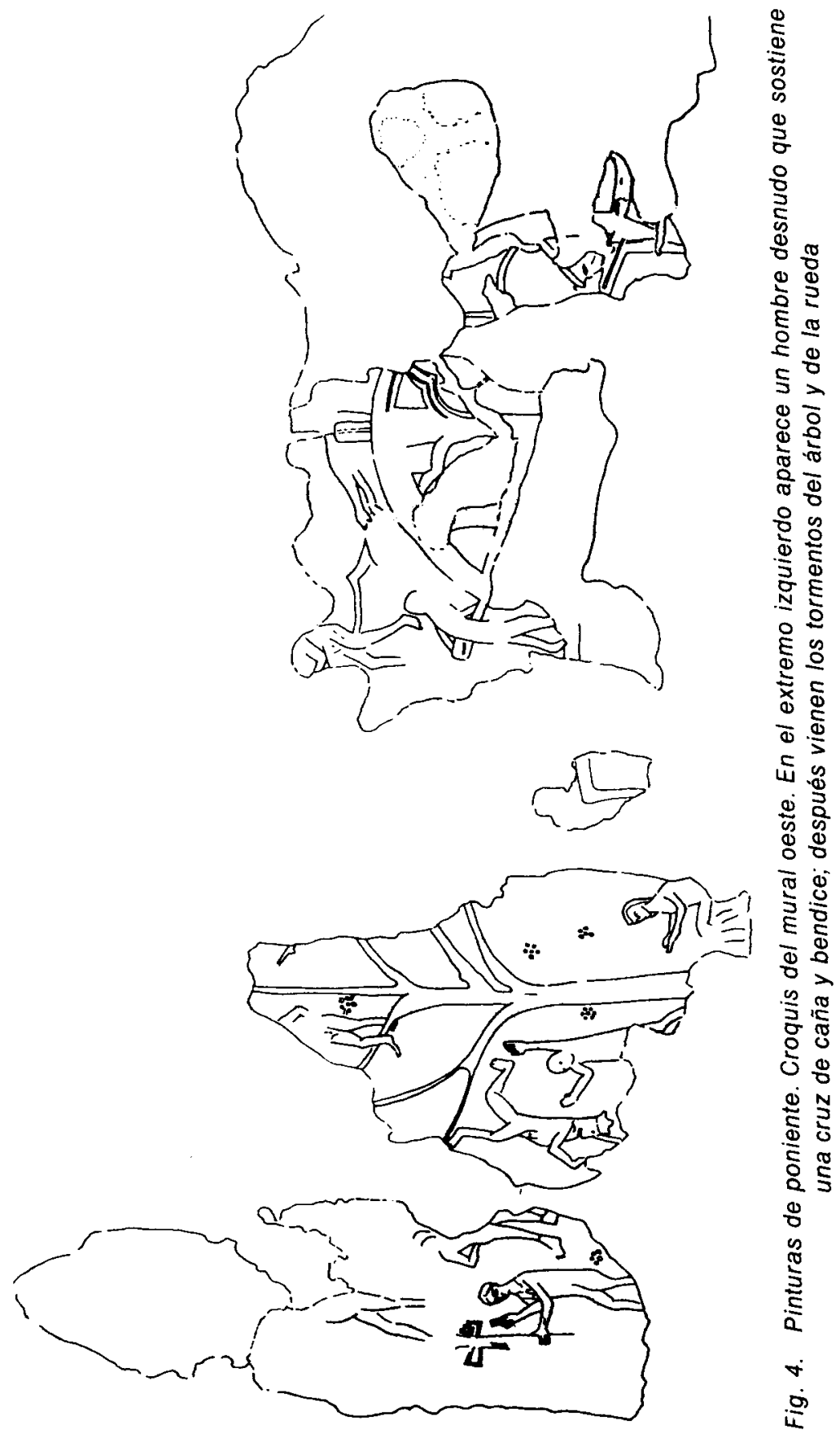




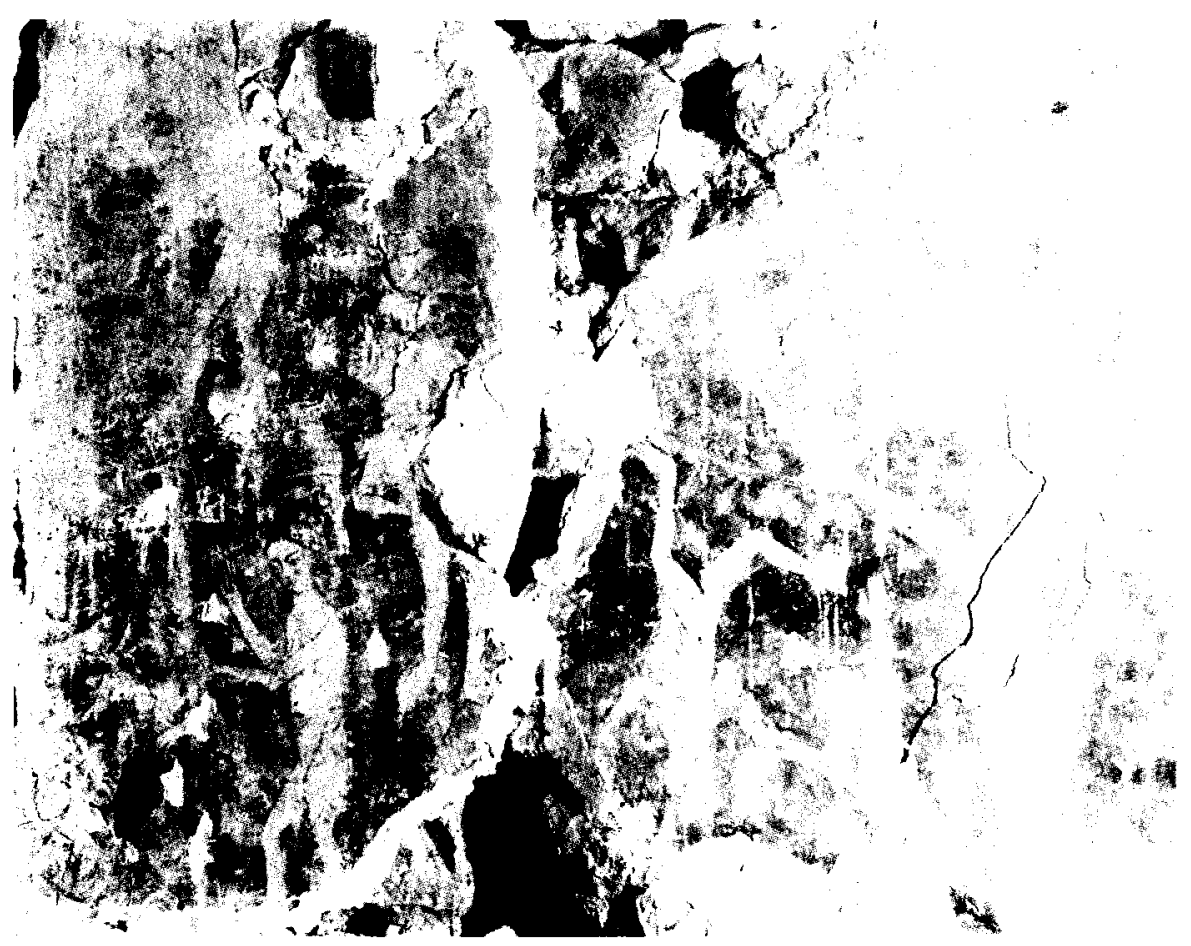

Fig. 5. Pinturas de poniente. Detalle de las escenas del muro oeste. A la derecha se aprecia el castigo del árbol igneo y a la izquierda aparece una figura que podria identificarse con san Juan Bautista

podría haber una rueda pequeña, en la que estaria atada la figura situada a la derecha del tronco.

La representación contigua consiste en una gran rueda amarilla, muy maltrecha y de la que únicamente quedan trozos de la zona superior y de la izquierda. Los radios son muy ornamentados y sobresalen de la propia curvatura de dicho instrumento. En el punto de intersección entre los radios y la rueda, están atadas figuras humanas desnudas. En el extremo superior se observan dos personajes ligados a un mismo vector, en cambio en la zona izquierda, una sola figura ocupa dos radios. Encima de esta última hay otro individuo que no parece pertenecer a la rueda, sino que flota en el espacio y se encamina hacia la derecha. El resto no es visible, pero seguramente las figuras rodearian la estructura circular del aparato. El fondo de la composición era de color negro, siendo todavía perceptible en ciertos lugares. El último fragmento pictórico importante se halla en la parte superior del muro, debajo del arranque de la bóveda. 
Está muy alto y en mal estado, ambas cosas dificultan en gran manera su identificación. Parece tratarse de una persona vestida con túnica negra y manto rojo, que también le cubre la cabeza. Lleva un objeto de color blanco colgado de la cintura, tal vez la funda de una espada. Aparece arrodillada en actitud orante.

Para terminar con la descripción de las pinturas de poniente, falta la decoración del muro norte situada en frente de las escenas meridionales. Su estado de conservación es bastante deficiente y además fue parcialmente destruida por la apertura de una capilla. Consta de dos composiciones (figs. 6, 7), de la izquierda sólo quedan fragmentos aislados que destacan sobre un fondo blanquecino salpicado de florecillas (trazadas esquemáticamente a base de puntitos rojos). Parece que hay una cabeza, posiblemente con nimbo, sobre la cual se posa un pájaro negro semejante a un cuervo (tanto por su color negro como por la forma del pico y las alas). El ave adopta una disposición arqueada para adaptarse al trazado de la cabeza. Delante de esta representación y algo separada de ella, aparece una mano con un dedo extendido y un pequeño orificio circular en el carpo.

La escena de la derecha se conserva mejor, está enmarcada por una cenefa de color rojo y negro que reproduce un motivo ornamental conocido con el término de acicate. En el centro de la composición aparece Cristo imberbe, vestido con túnica blanca con remates amarillos y manto negro. El nimbo crucifero rodea sus cabellos rubios y largos. El trazo ovalado de su rostro es el mismo que el de los condenados del muro sur, su boca es una línea, la nariz se une a la ceja derecha, en cambio la izquierda es bastante arqueda y, finalmente, unos ojos de forma triangular. Las manos se hallan perfiladas por una linea roja y las uñas están bien dibujadas. La figura aparece en posición frontal, con la mano derecha bendice y con la izquierda sostiene el globo terráqueo. Debajo de Cristo se advierte una persona, de la que se puede ver parte de su cabeza nimbada.

\section{Las pinturas del nordeste}

Se hallan en los muros septentrionales y oriental del brazo norte del transepto. Presentan profundas grietas y en algunos casos ha desaparecido la capa pictórica y el revoco de preparación. La decoración de la pared norte se divide en dos zonas (figs. 8,9). La mejor conservada está delimitada por el arranque de la bóveda. La composición tiene un fondo rojo y las figuras son bicromas, blancas y rojas. A la derecha, hay un caballo de perfil del que se ven el cuello y las dos patas delanteras, una 


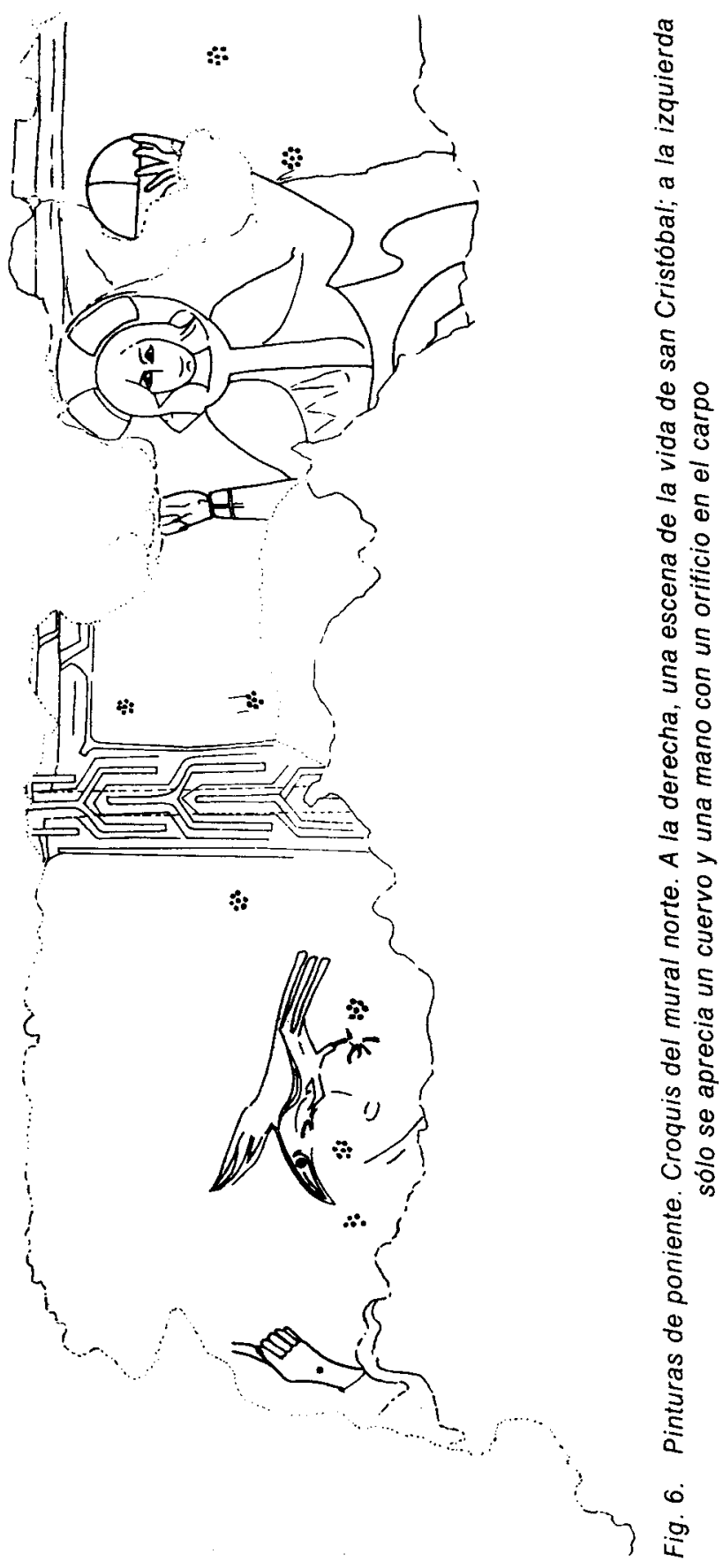




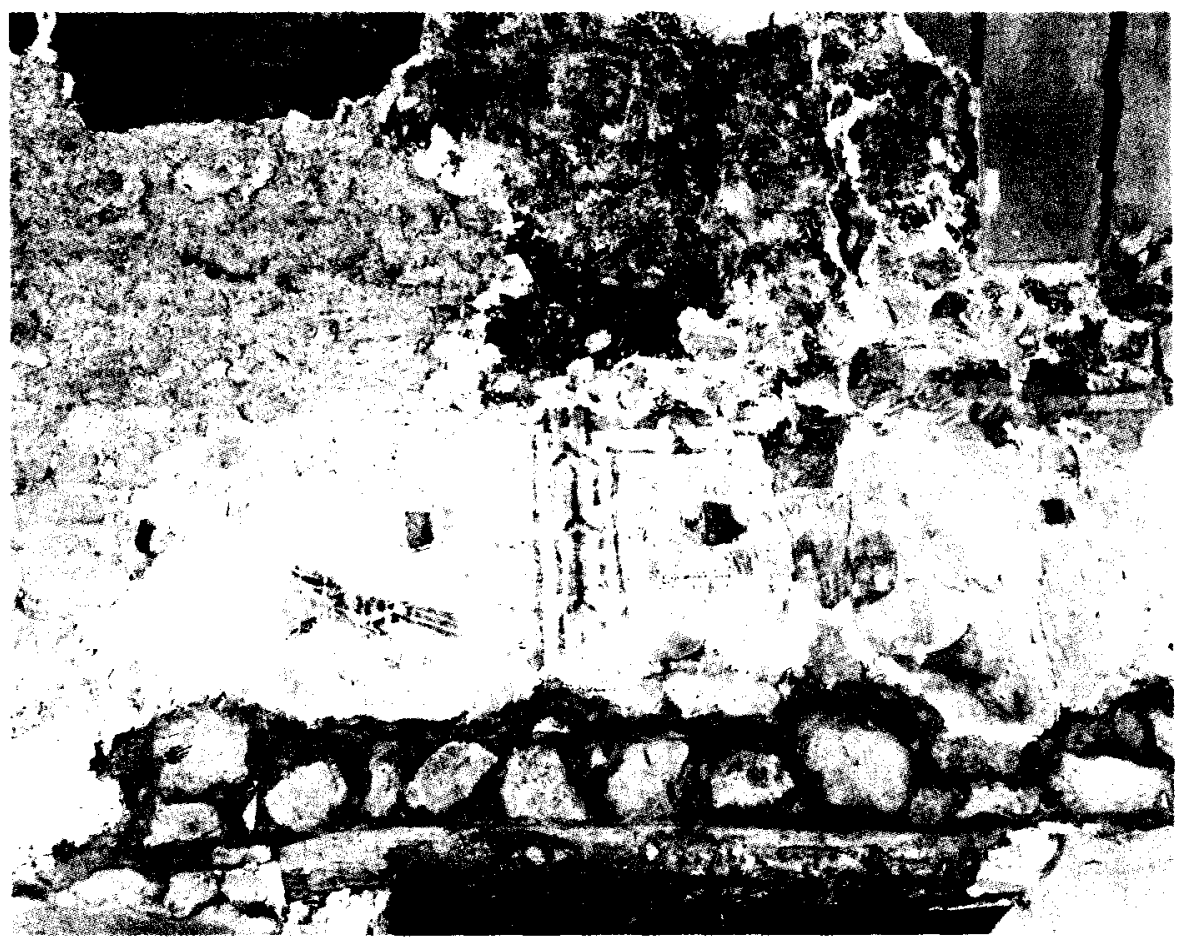

Fig. 7. Pinturas de poniente. Conjunto del muro norte. La escena de la derecha representa a san Cristóbal transportando a Cristo. La de la izquierda podria relacionarse con algún episodio de la vida de san Francisco

de ellas elevada; también quedan algunos fragmentos de las patas traseras y la cola. El jinete presenta los atributos de un caballero: traje corto con pliegues, espada al cinto, botas negras puntiagudas y espuelas. Con la mano sostiene una fusta de tres colas y descansa el pie visible en un estribo. Toda la zona superior se ha perdido y sólo quedan vestigios de la cabeza, observándose una cabellera rubia y un gran nimbo. Delante del caballo, aparece un hombre con el torso desnudo, faldellín y descalzo; se le representa de perfil, sosteniendo un cayado y dirigiéndose al caballero. Entre ambos personajes aparece un trozo de tela.

Debajo de esta composición, las escenas se organizan en tres compartimentos enmarcados por una orla decorativa formada por un tallo ondulado combinado con hojas trilobuladas de color negro. La escena central seguramente seria la más importante, debido a sus mayores dimensiones, aunque desgraciadamente sólo se han conservado dos cabecitas, una de ellas nimbada. De las dos laterales únicamente tenemos 


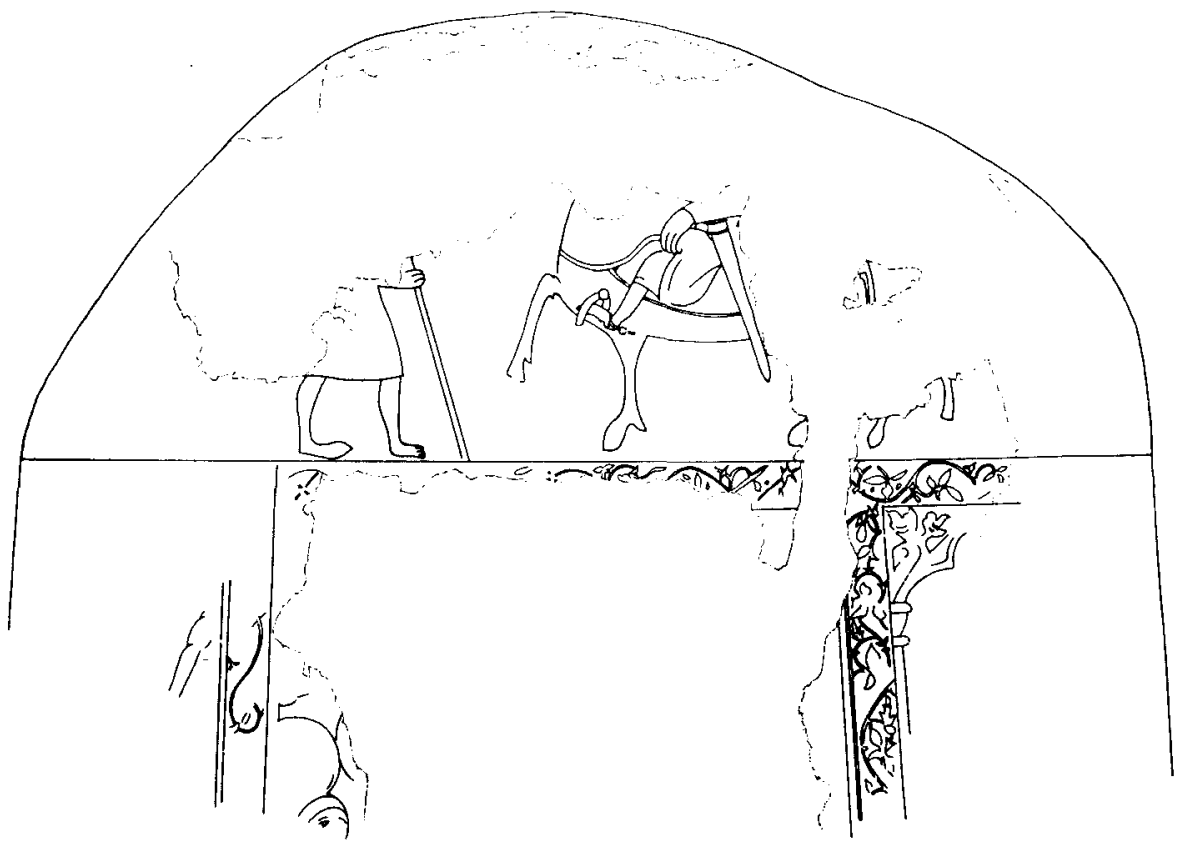

Fig. 8. Pinturas del nordeste. Croquis del mural norte: san Martin comparte su capa con un pobre

el encuadre de la derecha, idéntido al que aparece en el muro oriental de la misma estancia.

Las pinturas de la pared de levante también se han visto afectadas por el paso del tiempo y por la abertura de una hornacina (figs. 10, 11). El conjunto consta de dos registros separados por una cenefa ornamental a base de un tallo ondulante a partir del cual se desarrolla una composición de triples hojas acorazonadas. Cada uno de estos registros posee compartimentos rectangulares acabados en sendos arcos ojivales trilobulados con decoración de hojas de trébol y florón central, apoyados en columnillas. En cada rectángulo aparece un santo de perfil, con nimbo ondulado, cuyo nombre se especifica en una cartela sobre la cabeza.

Iniciaremos la lectura por el registro superior y de izquierda a derecha. El primer santo, sobre fondo rojo, viste hábito blanco y un manto corto sobre los hombros; su rostro es joven e imberbe y presenta tonsura. Como único atributo, sostiene un libro, y la inscripción con su nombre ha desaparecido. El segundo está de frente, lleva un hábito de color rojo 
Los frescos góticos lineales de la iglesia de Sant Valenti de les Cabanyes...

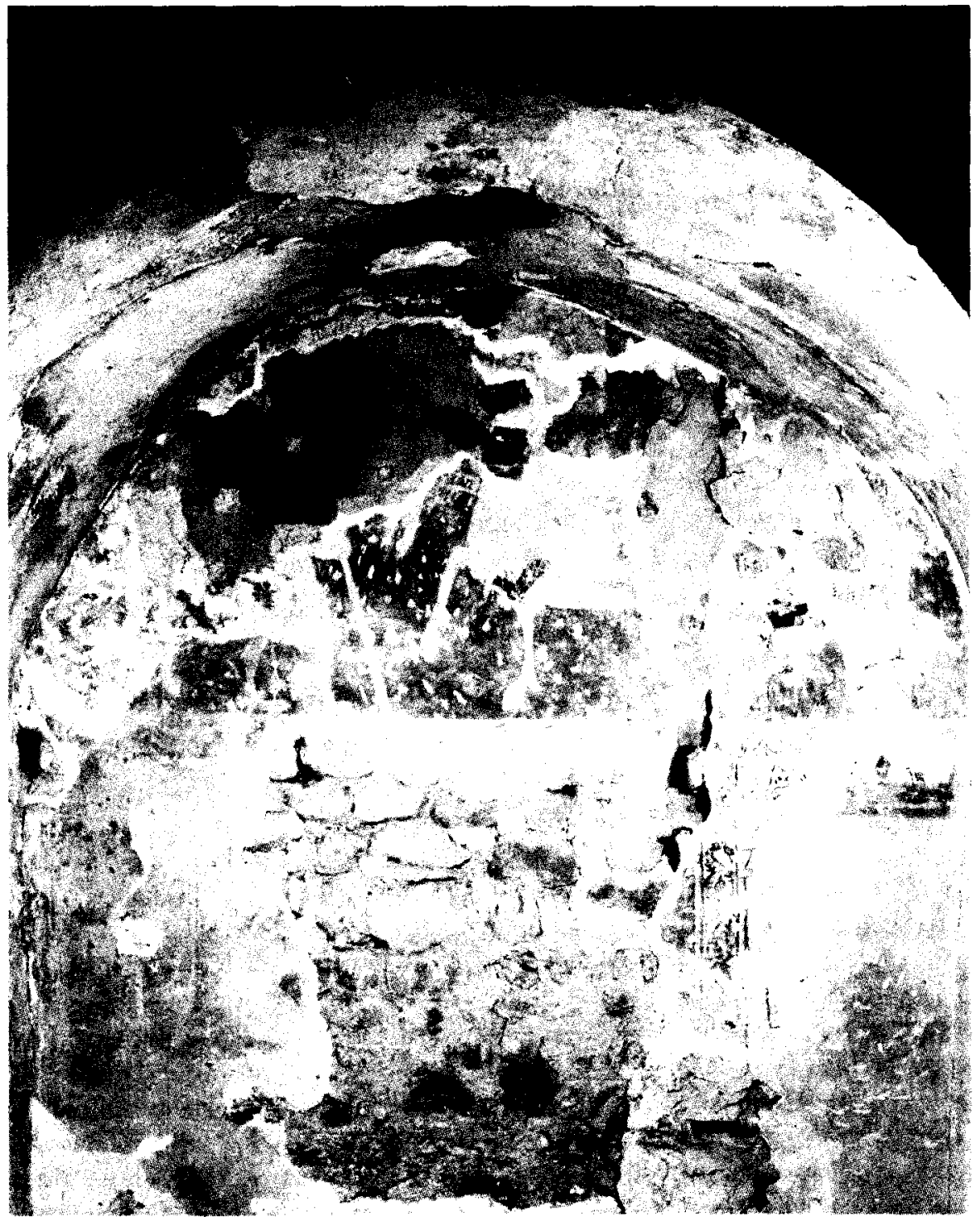

Fig. 9. Pinturas del nordeste. Conjunto del muro norte. La escena del que fuera obispo de Tours quizá fue elegida para destacar la importancia de la atención a los pobres 


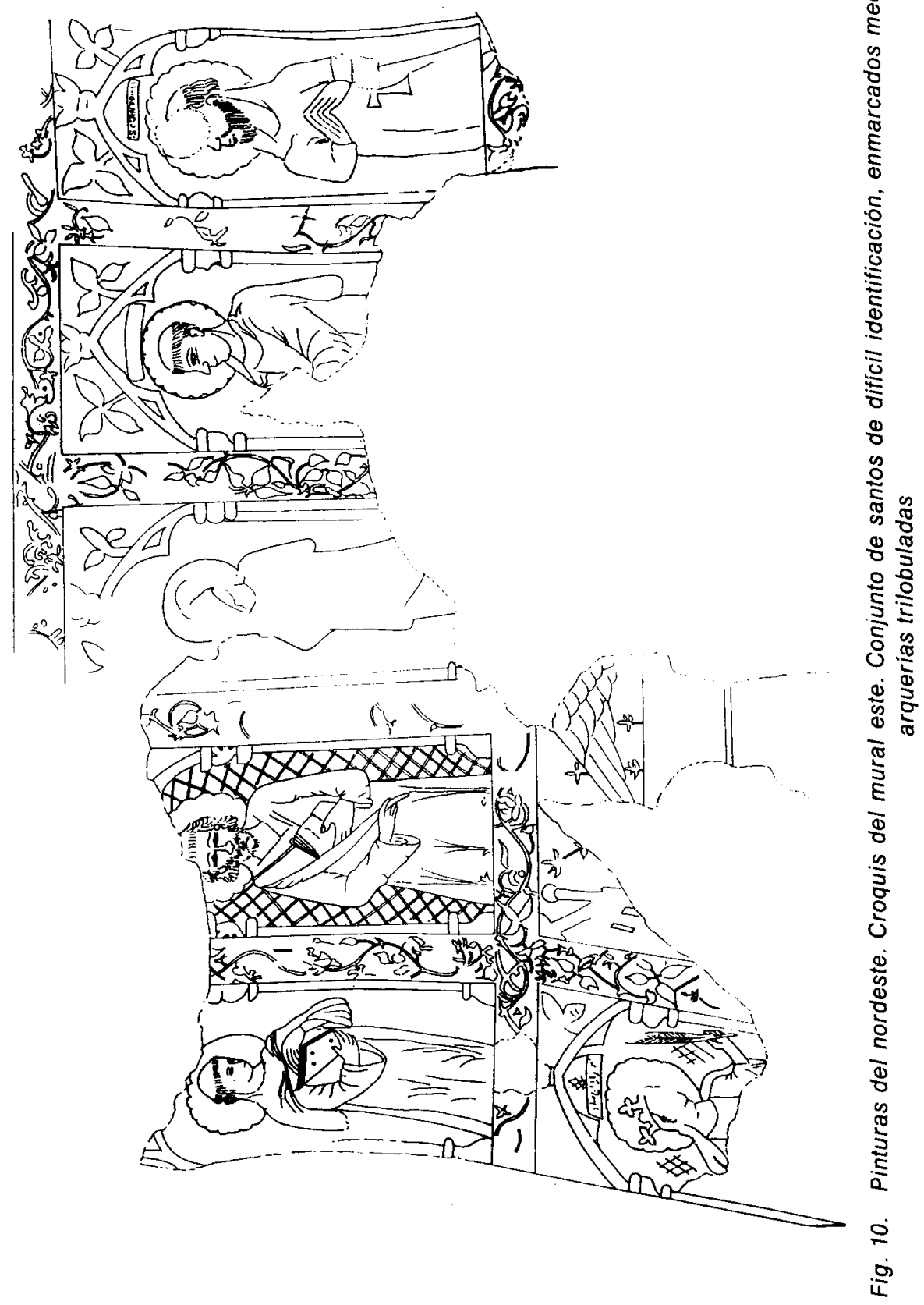




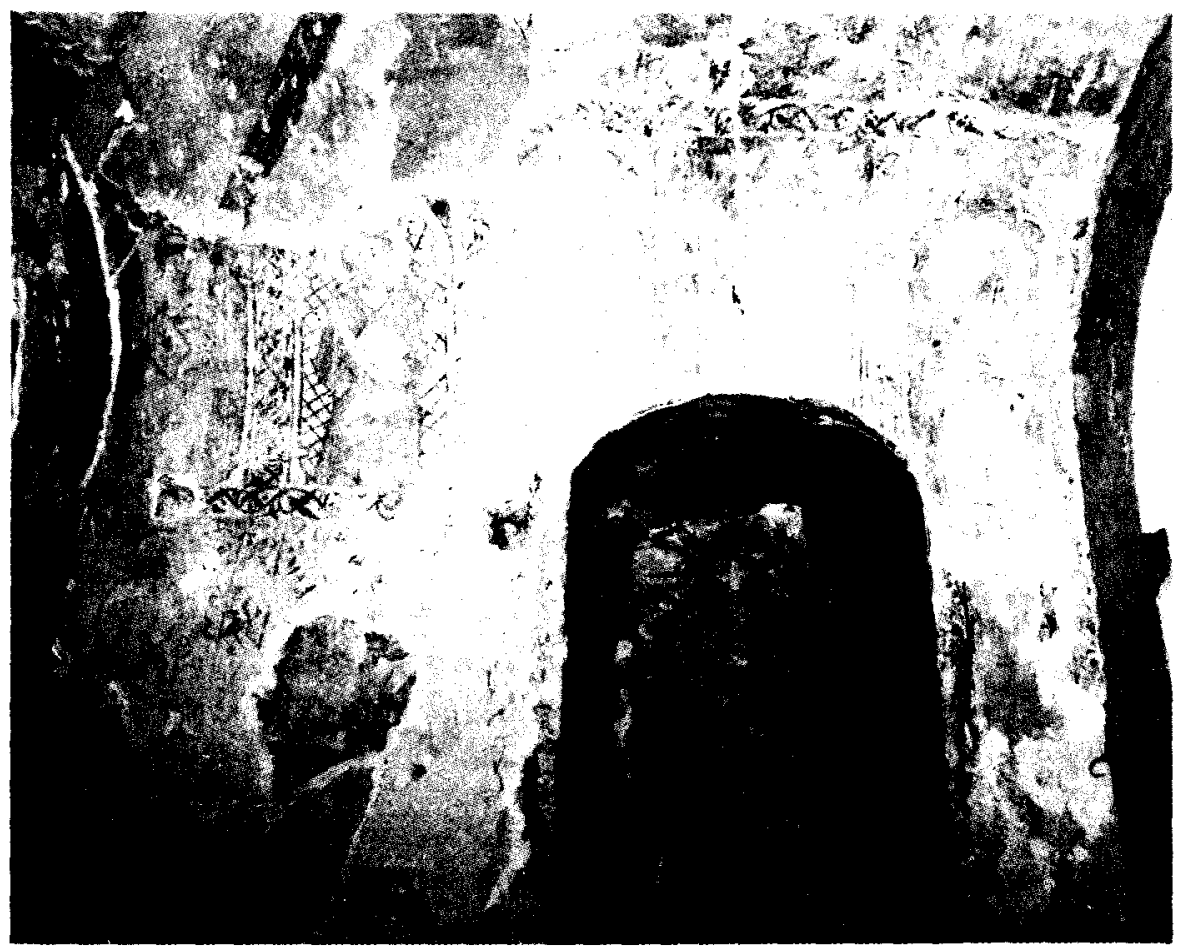

Fig. 11. Pinturas del nordeste. Conjunto del muro este. El santo situado en el último compartimento derecho del registro superior es san Antonio Abad.

intenso, es barbudo y tonsurado, sus únicos atributos son el libro sagrado y la palma del martirio. La figura destaca sobre un fondo reticulado y el epígrafe que lo identificaba está completamente destruido. El tercero tiene la cabellera rubia, la barba del mismo color, cubriéndose con una larga túnica blanquecina y un manto amarillo; no se distinguen sus atributos, está situado de perfil sobre fondo azul y no ha conservado la leyenda. Del cuarto sólo queda la mitad superior, pues el resto desapareció al abrirse la hornacina antes mencionada. Es imberbe y tonsurado, lleva hábito blanco con cogulla, siendo imposible determinar sus atributos. El título situado sobre el aura es muy difícil de leer, pero se puede distinguir la abreviatura de la palabra sanctus y algunas letras que podrian transcribirse como Bernardus o Benedictus (agradecemos al profesor Manuel Riu esta indicación). El último santo del registro superior también está de perfil, sus cabellos y barba son rubios, presentando tonsura; viste traje talar de color oscuro con capucha. Como atributos tiene una cruz en forma de 
tau, colgada de un brazo, y un ave, que sostiene entre las manos. La inscripción de la cartela puede transcribirse como Sanctus Antonius.

La descripción de los santos del registro inferior todavia es más ardua, debido al desprendimiento de buena parte del mural y la desaparición de alguna escena, a causa de la colocación de la hornacina referida. En el primer compartimento de la izquierda aparece una santa con túnica marrón y manto blanco, cubierta con velo, coronada y sosteniendo una palma de martirio. Destaca sobre un fondo reticulado, idéntido al del segundo santo del registro superior. Como el resto, tiene el nombre escrito en una cartela sobre el nimbo, pero el mal estado de las letras dificulta enormemente su lectura, aunque podria deducirse el nombre de Isabel (información M. Riu). De la siguiente escena sólo quedan algunos fragmentos, destacando los vestigios de una estructura arquitectónica de color amarillo y una parte del ala de un ángel. La decoración del último compartimento se halla en un estado tal de degradación que resulta imposible cualquier lectura.

\section{EL PROGRAMA ICONOGRÁFICO DE PONIENTE}

Creemos que se puede establecer una relación entre los diferentes temas plasmados en las paredes de los pies de la iglesia. De todas formas, debe tenerse en cuenta que no se trata de una representación lineal: en el muro oeste, junto con las penas del purgatorio, aparece un alma que se dirige a la salvación, dichas penas continúan en el muro sur, y en el paramento norte encontramos la escena de san Cristóbal con Cristo sobre los hombros y otros restos de dificil interpretación.

\section{Las penas del purgatorio}

El tema más desarrollado es la descripción de los castigos sufridos por los condenados en un lugar que podria interpretarse como el infierno o el purgatorio. Tanto en la literatura como en las formas plásticas, no existe una diferenciación clara entre estos dos espacios, pues presentan unas caracteristicas muy similares. Sin embargo, un elemento básico permite distinguirlos: mientras que en el purgatorio existe posibilidad de salvación, en el infierno la condena es eterna. Creemos que en nuestra iglesia se ha reproducido el purgatorio, puesto que una de las figuras del muro oeste escapa de las torturas y se encamina hacia el paraiso. 
En este conjunto figuran cinco penas concretas: el árbol igneo, la rueda, el tormento de los demonios, el fuego y la caldera; las dos primeras en el muro occidental y las restantes en el meridional. La situación de tales temas o los pies de la iglesia era normal y debe entenderse como un discurso opuesto a las visiones teológicas que, casi siempre, se representaban en la cabecera. Las fuentes literarias utilizadas por los artistas han preocupado a los estudiosos, dando lugar a una extensa bibliografía, pues fórmulas iconográficas semejantes pudieron ser inspiradas por textos dispares. Algunos autores creen que los únicos documentos usados fueron los cristianos, otros, en cambio, opinan que es necesario tener en cuenta los ciclos escatológicos musulmanes y las tradiciones judeo-cristianas (Cfr. un resumen en PACHECO 1973: 5-21).

El primer castigo es el del árbol ígneo, pintado a la izquierda del muro oeste (figs. 3,6 ). Consiste en un árbol amarillo, color que imita al fuego, que presenta un réprobo desnudo de pie sobre una rama y otros que caen a ambos lados del tronco. La tortura del árbol se recoge en dos documentos apócrifos: el Evangelio de Bartolomé y la Visio Sancti Pauli. En el primero, los demonios explican los suplicios que se infringen a los sentenciados, siendo uno de ellos el del árbol: «A unos les echamos al fuego, a otros les lanzamos desde los árboles para que se ahoguen; a unos les rompemos los pies o las manos, a otros les arrancamos los ojos" (SANTOS OTERo 1984: 563). Aún más interesante es el apócrifo paulino, que trata del descendimiento al infierno de este santo acompañado por el arcángel Miguel (escrito en el siglo $\|\mathrm{O}\| \mathrm{y}$ del que se conocen hasta ocho redacciones diferentes). El del árbol es el primer tormento infernal: «Et postea Paulus ductus ad portas inferni. Et uidit ibi arbores igneas, in quarum ramis peccatores cruciati pendebat: quidam per capillos, alii per pedes, alii per manus, alii per linguas, alii per colla, alii per brachia, alii per membra diuersa" (SIVERSTEIN 1935: 156).

Si observamos con cierto detenimiento el fragmento del fresco inspirado en este párrafo, podemos comprobar que el árbol igneo es bien visible pero los réprobos no cuelgan de él sino que se sitúan a ambos lados del tronco o encima de las ramas. En una miniatura del Infierno de san Pablo de Verger de Soulas (Baltrusaitis 1960: fig. 9) los condenados están atados del árbol por los pies y cuelgan cabeza abajo. En nuestros murales la representación plástica no coincide exactamente con el relato por causas imprecisas, tal vez porque no se conocia bien esta fuente 0 porque se hubiese utilizado otra.

Según Asin Palacios (1966: 282), esta primera visión del texto cristiano adopta la idea de un relato árabe, el viaje de Mahoma al infierno o Isra, del que hay dos ciclos. En la versión A del ciclo I, podemos leer el si- 
guiente comentario: «Y marchamos después y nos encontramos con unos hombres y con unas mujeres colgados de sus pantorrillas, con las cabezas abajo y chupando un poco de agua y un poco de cieno" (Ibidem 426).

En este caso no se especifica que el instrumento de tortura sea un árbol y se le añade el suplicio de la absorción de agua y cieno. En el segundo ciclo ocurre algo semejante aunque sea más próximo al texto paulino: “Después miré y vi a unas mujeres colgadas de sus cabellos. Dije: ¿Quiénes son éstas? respondió: Las mujeres que no ocultaron sus rostros y sus cabelleras a las miradas de los hombres extraños" (Ibidem 436). Este mismo autor, comenta que en las descripciones coránicas del infierno y en los haddits, la presencia del árbol infernal, llamado Zaqqum, es constante: «... es un árbol como los terrestres, que arraiga en el piso del infierno, y cuyo fruto amargo y repugnante es como cabezas de demonios" (ASIN PALACIOS 1943: 175, n. 1). Nosotros pensamos que la influencia de estos comentarios escritos no se explicita en el suplicio de los frescos objeto de análisis.

Las posiciones y gestos de las figuras situadas a ambos lados del árbol pueden deberse a un fuerte viento que las hace volar y las voltea. En un pasaje del Corán se alude a un viento que arrastra a los hombres situados en el primer ciclo del infierno: "Una nube o tempestad negra, un huracán oscuro y tenebroso...; un aire seco y asolador ruge y se agita violento...; al impulso veloz de sus ráfagas, que soplan sin cesar días y noches, arrastra cuanto encuentra: a su paso se ven volar hombre y mujeres llevados por los aires; la ráfaga los arrebata por debajo, los empuja, los alza y los arroja al suelo; es el viento nefasto y maligno de la divina venganza, suplicio doloroso de los pecadores..." (Ibidem 150).

Este castigo se sigue describiendo en relatos visionarios de fecha avanzada, como en El viatge a l'infern d'en Pere Portes, escrito en 1611: «Después véu un altre arbre tot foguejant, en lo qual estaven penjant 6 persones, les quals eren tutors de la persona i béns d'un tal Romaguera" (PACHECO 1973: 70).

Además de la consulta de las fuentes escritas también creemos que es interesante analizar la simbologia del árbol debido a su ambigüedad. El árbol es un simbolo que tiene un doble sentido: positivo, en tanto sirve para representar la ascensión del hombre resucitado, y negativo cuando el hombre cabeza abajo cae de sus ramas. La simbiosis de estos dos significados la podemos encontrar en una miniatura del Beatus de Girona. En algunas recensiones árabes se evidencia la duplicidad del árbol, que es a la vez instrumento de tortura y de salvación (Asín PALACIOS 1966: 83). San Vicente Ferrer, en uno de sus sermones sobre la muerte y el juicio, recurre al árbol como elemento de salvación: «... un hom una vegada, 
encepegà en una pedra e caigué en un gran pou molt pregon, per aventura del mil llances, e ell, aixi com caïa, tingué's a una rama de un arbre que era en mig loc... Ooh, bé estava en gran pena! Aquell se tenia en la rama de l'arbre, e no podia pujar, ne gosava davallar, e les rates menjaven-se les raïls de l'arbre" (Fuster 1955: 77). El árbol de nuestros murales podría tener ese doble significado ya que está a la entrada del purgatorio, entre una escena de condena y otra de liberación. En el infierno de la iglesia de san Pedro y san Pablo de Chaldon (Surrey) (OWEN 1970: fig. 6, fechado hacia 1200) el discurso escatológico se organiza en dos registros: en el inferior aparecen sendos suplicios infernales separados por una escalera, que a su vez delimita las composiciones del registro superior, donde se representan la psicostasis, la conducción de las almas y la anástasis. La escalera tiene una doble función: en los peldaños de abajo se hallan los condenados, volteados o en actitud forzada, que son recogidos por un demonio y depositados en la caldera; en los últimos peldaños, las criaturas suben tranquilamente hacia la zona de salvación, reproducida en la parte superior derecha. Creemos que la función y significado de esta escalera podrian ser idénticos a los del árbol de las pinturas objeto de estudio.

Los paralelos iconográficos sobre el árbol ígneo son escasos, quizá uno de los más significativos sea la miniatura del infierno de Verger de Soulas, del siglo XIV. Según Baltrusaitis (1960: 286), se trata de un tema poco usual en pintura mural y cita como único ejemplo el de la iglesia de Saint Désert de Châlons-sur-Saône, fechado en el siglo xv. Añade que el árbol fue sustituido rápidamente por una horca de la que cuelgan los pecadores (Ibidem 281).

En la siguiente escena, dificilmente conectable con la anterior al haberse perdido buena parte de la pintura, se describe el tormento de la rueda ignea (fig. 3). Si se observan los fragmentos con cierto detenimiento, se puede suponer la presencia de dos ruedas: la más pequeña y borrosa, estaria situada en el lado derecho del árbol y de ésta saldría disparada una figura; la otra, de mayores dimensiones y más completa, presenta una estructura curiosa en forma de rosetón, en cuyos radios están atados los pecadores.

Como en el caso anterior, las fuentes escritas que pudieron servir de inspiración son muchas y variadas. Según Silverstein (1935: 76), dicho castigo no aparece hasta la cuarta versión del apócrifo de san Pablo (... in quo est rota ignea habens mille orbitas, mille vicibus in uno die ab angelo tartareo percussa, et in una quaque vice mille anime cruciantur), y podria tener un modelo en un apocalipsis priscilianistico, que sitúa el tormento en el séptimo infierno. A partir de la cuarta redacción, este ins- 
trumento se halla situado entre los suplicios del árbol y del horno ardiente. En cambio, en el Misal de Toulousse, traducción provenzal del apócrifo, es el séptimo tormento y aparece asociado al paso brusco del frío al calor: "Iceus sur la reo mys sunt, freit e chaut graunt seuffrunt. Mil foiz les diables la reo turnerent. De freit e de chaut peinés erent» (MEYER 1895: 369). En el Evangelio de Bartolomé, también se le dedica un pasaje y además se describe la rueda: "He aqui que sube una rueda del abismo y tiene siete cuchillos de fuego. El primero de éstos tiene siete canales» (SANTOS OTERO 1984: 561). Según G. Llompart (1977, II: 187), una de las fuentes más utilizadas por los artistas medievales para representar las penas del infierno son las Actes de Llàtzer. En este texto la rueda sirve para castigar a los soberbios: «Primerament, jo vin rodes molt altes sitiades en una gran muntanya tostemps rodants subitament ab gran brogit, axi com a moles de molins, en les quals staven peniats los superbiosos, o ànimes de aquells". Se trata de un documento muy interesante para los frescos analizados, ya que enumera varias ruedas (nosotros creemos que posiblemente en el purgatorio de Sant Valenti habría más de una), que presentan una tipologia especifica (hay que recordar que el tipo de rueda de estos murales no es la usual). Además, sabemos con certeza que este escrito fue utilizado en algunos conjuntos plásticos, como en el infierno de la iglesia de Saint Étienne de Jaillons, donde tres grandes ruedas sirven para martirizar a los orgullosos, dicha imagen se acompaña de una inscripción que reproduce las palabras de Lázaro (Roques 1961: 49).

Esta pena se describe minuciosamente en la mayoría de los relatos visionarios, en los que se explica cómo los demonios se encargan de accionar la rueda a la que están atadas las criaturas, que van dando vueltas constantemente. El Viaje de san Brandán, escrito en el siglo v, es uno de los primeros: "El lunes, dia y noche, en la rueda estoy dando vueltas, yo cuitado, alli colgado, giro tan rápido como el viento; cada dia me voy, cada día vuelvo, con los vientos llevado en la rueda por todo el aire» (BENEDEIT 1983: 47). También aparece en el Viatge del cavaller Owein al Purgatori de Sant Patrici, traducido al catalán en 1320 ("Apres daç, aparech a els una rode a foch, de mareueyllosa granea, de las qual los raygs e les cantons de ganxos de fferre de foch plens eren, e en cascu daquels homens ficats penyauen", Miouel y PLANAS 1914: 19) y en el Viatge del vescomte Ramón de Perellós al Purgatori de Sant Patrici. También fue un motivo recurrente en las representaciones teatrales; en el Auto de acusación contra el género humano, Satanás, Lucifer y Carón piden a Dios que les devuelva el género humano, que consideran suyo, mientras que la humanidad, atada a la rueda, replica contra las presiones del infierno y pide ayuda a los ángeles: "Dadme horden como pueda librarme de tanto afán, vos vereys si por mí queda. Ay que en esta triste rrueda me dejó 
mi padre Adán" (Historia de la Literatura Española. Teatro Medieval, 1983, 31: 166). La profesora B. Mariño (1989: 164) comenta que la rueda era un suplicio usado en la Antigüedad y en la Edad Media y uno de los instrumentos de tortura aplicado a los calumniadores.

Parece ser que este suplicio también tenía una larga tradición en los relatos musulmanes, sobre todo para castigar a los sabios que no se comportaban de acuerdo con sus enseñanzas. En este primer caso, no hay una referencia explícita a la rueda sino que más bien se debe relacionar con su movimiento giratorio: "Lanzados al infierno, se verán forzados a dar vueltas continuas sin descanso ni reposo, como el asno alrededor de una noria o una muela, o de una tahona" (Asin PALACIOS 1943: 153). En cambio, en algunos haddits la similitud con el apócrifo paulino es evidente (hasta tal punto que se ha llegado a suponer que éste último se habría inspirado en lo musulmán), sobre todo el escrito por Abu-I-Mutaná al Umluki en el siglo xill: «Hay en el infierno gentes atadas a ruedas ígneas de noria, que giran con ellos sin descanso ni reposo" (Ibidem 1966: 283). La profesora M. Melero, en su estudio sobre la Puerta del Juicio de la catedral de Tudela, hace un estudio de esta pena infernal (que aparece esculpida en la séptima arquivolta del lado del infierno) y considera que las fuentes usadas para la concreción de la fórmula iconográfica serían una suma de textos escatológicos cristianos, musulmanes y judeo-cristianos. Nos obstante, en el caso de Tudela opta por dar preferencia a las fuentes musulmanas debido a una serie de consideraciones, entre las que cabe destacar, una mayor aproximación entre el relato escrito y la formulación plástica, y el hecho de que en los textos cristianos no se relaciona este tormento con ningún pecado concreto (sin embargo, conviene recordar que en las Actes de Llàtzer la rueda sirve para castigar a los soberbios).

Dicho tormento aparece muy frecuentemente en las representaciones miniadas, en el Comentario de Beatus al Apocalipsis de la Biblioteca Nacional de París (Lauer 1927: fig. 29, escena del Juicio Final. Este autor cree que el manuscrito procede del monasterio de San Andrés de Arroyo y se puede fechar en el siglo XIII) la rueda con los pecadores se halla en el interior del infierno; en el Salterio del Trinity College, fechado hacia 1220 también se reproduce dicho instrumento. En el Infierno de San Pablo de Verger de Soulas, la composición es muy completa: en una especie de rueda de carro situada en el extremo de un largo bastón, aparecen atadas las almas por diferentes partes del cuerpo. A su derecha se encuentra el demonio encargado de darle a la manivela y a la izquierda hay dos diablillos, san Pablo y el arcángel Miguel. En el Infierno de Guillaume de Deguieville (Biblioteca Nacional de Paris, de hacia la segunda mitad del siglo XIV, SUREDA 1981: 377) los tres condenados desnudos se adaptan a 
la curvatura de una rueda sencilla, formada por seis radios unidos a un disco central. A ambos lados aparecen una torre alta (derecha) y dos demonios negros tan altos como ésta (izquierda). En el Misal Bodleian (OWEN 1970: fig. 1, del siglo XV) los penados están atados a la rueda por las extremidades inferiores y a la vez son atacados por serpientes. El instrumento también es activado por un demonio situado a la derecha de la composición.

Respecto a la escultura uno de los paralelos más interesantes, aunque bastante alejado del nuestro, es la rueda de la portada de Tudela antes referida, en la cual los condenados están enganchados por la lengua, además de ser fustigados por un demonio mediante un gran martillo. Al tiempo que dan vueltas van mojándose en un río.

Este tema es poco frecuente en la pintura mural, no obstante hemos encontrado un paralelo bastante significativo: el infierno de la iglesia de Asnières-sur-Vègre (PRÉ 1953: fig. 13; ibidem 1956: 1, lo fecha a principios del siglo xiII; Duschamps, Thibout 1963: 102-103, piensan que puede ser de mediados de la misma centuria). El conjunto puede dividirse en dos registros, de los cuales ahora nos interesa el inferior, donde aparece una gran rueda accionada por un demonio de dimensiones considerables, a la que se han atado los condenados en posiciones diversas (desgraciadamente esta pintura está bastante degradada, a ello hay que añadir la deficiente calidad de la reproducción fotográfica; ambas causas dificultan bastante su lectura). Parece ser que en los frescos de la iglesia de Saint Étienne de Jaillons, también se reproduce esta pena (RoQUES 1961: 49, no publica ninguna reproducción fotográfica). Un poco posterior, anterior a 1480, es el Juicio Final de la catedral de Albi, donde aparece la rueda posiblemente siguiendo el texto apócrifo de Lázaro (MEsuret 1967: 232234).

El resto de castigos se halla situado en el muro sur de la nave, y reproduce una serie de torturas típicas del purgatorio y el infierno, bien descritas en la literatura escatológica y frecuentes en los conjuntos plásticos. Por una parte, tenemos a dos demonios que fustigan a los pecadores, que además queman en el fuego, y por otra, el baño en la caldera. Creemos que la lectura óptima es de derecha a izquierda, tanto por la posición de los personajes como por el hilo narrativo y por el orden seguido en los paralelos. En la primera escena (figs. 2, 5) se representan dos castigos diferenciados, pero perfectamente interrelacionados: los condenados cuelgan de los cuernos de Satán y son lanzados a unas enormes llamaradas que empiezan a quemarlos. La tortura del fuego, sin estar relacionada directamente con los demonios, es una de las penas más usuales en los textos cristianos. Ya aparece en el evangelio de san Mateo (25, 
41: «Al mismo tiempo dirá a los que estarán a la izquierda: Apartaos de mi, malditos, id al fuego eterno, que fue destinado para el diablo y sus ángeles») y en el Apocalipsis (20, 14: “Entonces el infierno y la muerte fueron lanzados al estanque de fuego. Ésta es la muerte segunda, el estanque de fuego"). San Agustín, basa su visión escatológica en el fuego de purgación (LE Goff 1989: 98-102). Asimismo, son significativos los Diálogos de san Gregorio (1968: 82), en los que se introducen algunos exemp/a referentes a dicho suplicio, como el de un tal Pedro que muere y al resucitar, explica su visión del infierno al monje lliriciam, del monasterio de San Gregorio: «e dix (Pedro) que havia vist infern e moltz locs plens de foc, en los quals viu moltz poderosos d'aquest segle, aqui penjatz a les flames».

La literatura escatológica apócrifa ofrece descripciones que pueden resultar útiles. Las diferentes versiones de la Visión de San Pablo narran una escena truculenta que ocurre en el infierno: en medio de este espacio hay un ser (dragón igneo con tres cabezas y mil dientes) o seres diabólicos (bestias con cara de lobos) que devoran las almas de los réprobos, e inmediatamente, son depositados en un río igneo (se establece una relación entre la inmersión de los diferentes miembros del cuerpo y los pecados cometidos). Tal vez no se trate de una fuente muy directa ya que no vemos demasiadas coincidencias con las fórmulas utilizadas en nuestras pinturas.

En cambio sí creemos que hay una mayor relación con algunas novelas visionarias, concretamente con la Visió de Trictelm (texto de los siglos VII-VIII, recogido por Beda el Venerable e inspirado en el texto paulino): «e viu companya de dimonis malignes que tres animes domens cabuçaven e turmentauen... e tirauen los, e aualaren en mig de les flames de foch ardent, los peus amunt e los caps auall» (MIQuel y PLANAS 1914: 124-125). También aparece en el Viatge del cavaller Owein al Purgatori de sant Patrici (Miquel y Planas 1914: 18 y en el Viatge del vescomte Ramón de Perellós. FACHeCo 1973: 42, 44-45). San Pedro Pascual, en su Disputa del Obispo de Jaén contra los judios de la fe católica (escrita el año 1300 en Granada cuando estaba preso de los árabes) enumera los cuatro infiernos que existen y las penas respectivas, en el tercer infierno se quema a los que no han hecho suficiente penitencia: «En lo ters infern es pena de foch...e aquell lloch es apellat Purgatori, e en aquell avallen tots aquells qui en quet mon, no han cunplida la penitencia de llurs pecats, dels quals no han feta penitencia, e apres de quet purgatori, van en la gloria celestial" (ARMENGol 1907: 185)

Paralelamente, en otras religiones también existe literatura referida al fuego y no podemos descartar como fuente de inspiración. Según Le Goff 
(1989: 39), en el sheol hebreo se castiga al condenado sujeto por un lazo y sumergido en el fuego (recordemos que en estas pinturas algunos de los condenados están colgados de pies o manos mediante una lazada). Esta forma de tortura procede del Antiguo Testamento, y la encontramos en Samuel (2 Sam 22, 6: "Con las fajas mortuorias estuve ya atado, y hálleme cogido en los lazos de la muerte»), en Job (18, 7-10: "Sus briosos pasos quedarán cortados, y su mismo consejo le llevará al precipicio. Porque ha metido sus pies en la red y anda entre sus mallas. Su pie quedará cogido en el lazo, y arderá de sed por pillarle. Escondido está en el suelo el lazo y armadas en las sendas las redes"), y en los Salmos (18, 6: "Las cuerdas del infierno me envolvieron, me invadieron los lazos de la muerte»; 116, 3: «Las cuerdas de la muerte me ciñeron, prendiéronme los lazos del infierno, caí en angustias y miserias»). Según M. Melero (1984: 294, n. 9), el castigo del fuego también aparece en las fuentes musulmanas y se aplica tanto a los pecados en general como a los concretos. Dicho tormento se sitúa en el último circulo infernal y castiga de acuerdo con el grado de las culpas: “El fuego conocerá perfectamente la gravedad relativa de las culpas y de las penas que los réprobos merezcan... Y así, a unos les alcanzará sólo hasta los tobillos, a otros hasta las rodillas, a otros hasta la cintura, a otros hasta el pecho, a otros hasta el cuello" (Asin PALACIOS 1943: 169). En una descripción infernal atribuida a Ibn'Abbas se dice que unos serán castigados de pie mientras que otros lo harán con la cabeza hacia abajo (Ibidem 155, n. 3). Igualmente son quemados los que cometen pecados especificos como el asesinato, el adulterio, la simonia y los que odian a los padres y no respetan al prójimo. El tipo de tortura que se infringe a los que no respetan ni a los padres ni al prójimo se narra en la redacción B del ciclo II del Isra. Los primeros son atormentados por los demonios y por el fuego: "Después vi unos hombres y mujeres que eran atormentados en el fuego. Unos demonios encargados de su suplicio, los sujetaban con unos garfios de hierro... Dije: ¿Quiénes son éstos? Respondió: Los que odiaron a sus padres", y los segundos son colgados del cuello: "Después vi a unas gentes con argollas de fuego, como montañas, puestas en sus cuellos. Dije: ¿Quiénes son éstos? Respondió: Los que no cumplen fielmente sus compromisos con sus prójimos" (Asin Palacios 1966: 436-437).

Después de haber analizado los principales textos literarios referidos a este castigo creemos que resulta difícil elegir una fuente de inspiración concreta ya que, debido a la similitud de contenidos, podrian haberse utilizado indistintamente diversos textos.

A continuación viene el suplicio de la caldera que forma una misma escena con el castigo anterior (fig. 2, 5). Se trata de una tortura muy representada en la escultura monumental (sobre todo en las portadas de 
las catedrales francesas de Conques, Bourges, Nôtre Dame de Paris y Reims, entre otras) y con menos ejemplos en la miniatura y en la pintura mural. Según E. Mâle (1953: 425), los artistas del siglo xIII sitúan este suplicio en el interior del infierno (simbolizado como una cabeza de monstruo con la boca completamente abierta) en función de una interpretación debida a san Gregorio: "Las Ilamas surgen de la boca, una humareda sale de los orificios de la nariz, y él hace hervir el fondo del mar como una caldera». B. MARINo (1989: 158, n. 5) opina que este objeto de tortura tiene un precedente en el Apocalipsis, en el que se hace referencia a un pozo $(9,2$ : «Y abrió el pozo del abismo, y subió del pozo un humo semejante a de un gran horno, y con el humo de este pozo quedaron obscurecidos el sol y el aire»), y que la principal fuente escrita debió ser el apócrifo de san Pablo, que a su vez sirvió de modelo a los relatos visionarios y a las representaciones teatrales. Sin embargo, en ninguna de las redacciones de la visión paulina aparece la caldera, lo único que se le asemeja es el horno igneo, en cuyo interior queman las almas de los pecadores que no cumplieron la penitencia terrenal que les correspondia por las faltas cometidas: “Et iterum vidit fornacem ardentem per VII flammas in diversis coloribus et puniebatur in ea pecatrices anime... et en illa fornace anime peccatorum mittebantur qui non egerunt penitentiam post pecata commissa in hoc mundo... Ibi cruciantur et recipiunt omnes seccundum opera sua..." (MEYER 1985: 366).

Posiblemente este horno se transformó en caldera debido al carácter más plástico del segundo objeto y para adaptarse a algunas fuentes escritas. En el Viatge del caballer Owein al Purgatori de Sant Patrici, aparece una especie de silo lleno de metal fundido, en cuyo interior los condenados son obligados a bañarse ( $E$ com lo caualler agueren mes dedins, vee visio molt cruel e orrible: car lo sol de la casa ho lo pahiment tot ere ple de ciges rodones, que tan espese e tant prop era la una del altra, que apenes entre elles gosare hom anar. Eren emperestirs cascun dels ciges plenes de diverses metaylls e licors bullens, en les quals era cuyta e bolida e torrada gran multitut domens, dels quals los uns eren tots lains cabuçats, e meses los altros entro a les ceylles... Miquel y PLANAS 1914: 20), en las Actes de Llàtzer, ya aparece la caldera llena de metales y reservada a los avariciosos: "Tercerament, jo viu grans calderes e olles plenes de coure e de molts altres metals, en los quals calderes e olles, los metalls eren molt bullents, e en los quals lochs eren forçats de entrar los avariciosos e per forsa alli staven" (LLOMPART 1977, II: 117). Como en el caso del suplicio de la rueda éste es uno de los documentos que consideramos más factibles como fuente de inspiración (en el infierno de la catedral de Albi el castigo está identificado con una descripción que repite las palabras puestas en boca de Lázaro, Mesuret 1967: 232). 
En los textos musulmanes tampoco se especifica el uso de la caldera sino que, como en el apócrifo paulino, se trata de un horno de fuego que sirve para castigar a los adúlteros (Melero 1984: 209, n. 48).

Este suplicio está recogido en el ciclo II de la versión B del /sra: «Después miré y vi unos hombres y unas mujeres en unos hornos, y el fuego encendiase sobre ellos y la llama subia hasta sus caras y sus cabezas... ¿Quiénes son éstos? Respondió: Las adúlteras y los adúlteros" (Asin PALACIOS 1966: 436).

Los principales actores de estas escenas son los diablos. La iconografia demoniaca ha sido estudiada por el profesor J. Yarza (1980: 231255) sobre todo la que aparece en los Beatus, aunque también se hacen alusiones a la gótica. En el gótico, los demonios se caracterizan por poseer un cuerpo peludo, patas con espolones, cornamenta y gesto feroz (lbidem 237). Los dos diablos que hay en el muro sur de la nave de la iglesia de Sant Valentí presentan un cuerpo humanoide, sobre todo el menor de ellos, y su cabeza se asemeja a la de un animal que recuerda respectivamente un ciervo y una especie de lobo. Ambos hacen gestos exagerados y están situados de perfil (según Yarza dicha posición tiene un significado negativo, ibidem 63). M. Villier (1957, Ill: 142-238), opina que la apariencia animal de los diablos proviene de la tradición judia, recogida por Origenes. En un primer momento, aparentan aves de rapiña y después se transforman en los animales terrestres más alejados de Dios: lobos, serpientes y zorros. El diablo situado a la izquierda de la composición presenta una tipología usual en la pintura gótica lineal catalana (demonio que participa en la psicostasis del frontal de Sant Miquel de Soriguerola, actualmente en el Museo Nacional de Arte de Cataluña). Más difícil resulta encontrar paralelos para el que está situado a la derecha, tanto por la forma como por el hecho de que lleve colgados los condenados en lugar de comérselos.

Para todo este conjunto meridional hemos hallado un paralelo iconográfico significativo, nos referimos a una de las miniaturas de las Concordancias Biblicas, de la Biblioteca Nacional (el texto es una refundición de la Summa de Joaquin de Fiore, con referencias a la historia de Aragón, y está fechada en el siglo XIV, DeLCLAUX 1973: 158-159). La composición a la que aludimos trata del Juicio Final, habiéndose reproducido el infierno en su registro inferior. De la parte baja emerge un monstruo con la boca bien abierta por donde entran los condenados, un poco más arriba aparece un demonio de perfil (tiene la boca entreabierta, una nariz prominente $y$ un ojo frontal). En medio de la cabeza ostenta un cuerno que atraviesa el cuerpo de una mujer desnuda. A la izquierda de éste se representa un segundo diablo, más pequeño pero de cuerpo entero, que 
tiene la función de conducir a los castigados hasta la caldera y entregarlos a Satán. Todavia hay un tercer demoniejo, con una cesta sobre las espaldas, encargado de transportar a los penados que son lanzados al infierno por los ángeles (quizá las cuatro cabezitas humanas, situadas al lado del demonio encargado de la caldera, conservadas en el muro sur de nuestra iglesia, corresponderian a los réprobos metidos en el interior de la cesta). Tanto por la tipología de los demonios como por la forma de los castigos y la composición general, creemos que se trata de un paralelo significativo.

En los frescos de la iglesia de Asnières-sur-Vègre (PRE 1953: fig. 13) también están reflejados los dos suplicios. En el registro superior, aparecen Satán y el demonio transportador y, en el interior, la escena de la caldera. A pesar de las diferencias, en los tres casos coinciden la tipologia de las figuras y el relato explicativo.

\section{La posibilidad de salvación}

En el conjunto de escenas de tormento que ocupa los muros occidental y meridional de la iglesia hay una figura que rompe con el relato iconográfico (figs. 3,6 ), concretamente el personaje situado en la pared oeste, delante del suplicio del árbol ígneo. Se trata de un hombre desnudo, con el brazo derecho levantado haciendo el gesto de bendición o aviso y sosteniendo una cruz de caña, con el izquierdo. Parece que está encaminándose hacia un espacio contrario al del purgatorio. El profesor J. Sureda (1981: 369) interpreta esta figura como la de un alma que ha conseguido superar todas las pruebas infernales y que se dirige hacia la salvación. No conocemos paralelos, ni literarios ni plásticos, en que un alma cualquiera lleve este tipo de cruz y menos aún que haga el gesto de bendecir. Ambos atributos suelen corresponder a Cristo o, en todo caso, a personas sagradas. Todo ello nos ha sugerido que, en lugar de haberse representado un alma anónima, podría tratarse de la liberación de un santo.

La mayoria de textos cristianos que describen el descendimiento de Cristo al infierno comentan que cuando éste entra se encuentra con una serie de personajes conocidos: Adán y Eva, Abrahan, Juan Baustista, David, los Reyes, los Profetas y los Patriarcas. Además, sabemos que la capilla de Sant Valenti fue una encomienda de la orden de San Juan del Hospital de Jerusalén, fundada bajo la advocación espiritual de Juan Bautista. Por ambos motivos y por los atributos comentados pensamos que el alma podria representar a san Juan. En el evangelio de san Lucas ( 3 , 15-17), dicho santo es considerado una prefiguración del Cristo-Juez que conducirá a los buenos al cielo y lanzará a los malos al infierno: "Como 
el pueblo estaba expectante y todo el mundo se preguntaba en su corazón si Juan tal vez era el Mesias, a todos respondió Juan: Lo que soy yo, os bautizo con agua; pero el que es más fuerte que yo, del que no soy digno de deshacerle la correa de sus sandalias: él os bautizará con el espíritu santo y con fuego. En su mano tiene el cedazo para limpiar la era y recoger el trigo del granero, mientras que quemará la paja con el fuego inextinguible». Orígenes hace unos comentarios a este pasaje en su Homilia XXIV: "Del mismo modo que Juan junto al Jordán entre aquellos que venian a hacerse bautizar, acogia a unos, a los que confesaban sus vicios y sus pecados, rechazaba a otros diciéndoles: "Raza de viboras, etc.», el Señor Jesucristo se mantendrá en el río de fuego cerca de una lanza de fuego, a fin de bautizar en este río a todos aquellos que no tengan el signo de los primeros bautismos, no los bautizará en el baño de fuego. Es preciso en efecto, haber sido primero bautizado en el agua y el espiritu para que, cuando se llegue al río de fuego, pueda demostrarse que se han conservado los signos de los baños de agua y de espíritu, por lo que se es merecedor de recibir entonces el bautismo de fuego en Jesucristo" (LE GofF 1989: 71). San Ambrosio llega a unas conclusiones similares (Ibidem 77). Así pues, Juan Bautista es considerado, al igual que Cristo, conductor de las almas buenas al paraiso, ya que realiza el primer bautismo. En este texto queda patente que todas las almas, incluso las buenas, antes de salvarse han de pasar necesariamente por el purgatorio.

Algunos evangelios apócrifos dedican un apartado amplio al tema del descendimiento de Cristo a los limbos, el más extenso de ellos es el Descensus Christi ad inferos, que forma parte del Evangelio de Nicodemo. En la versión griega de dicho apócrifo, Juan Baustista es considerado el último profeta y el enviado de Cristo a los infiernos para anunciar su llegada y próxima salvación "(Después salió al medio un asceta del desierto, y le preguntaron los patriarcas: ¿Quién eres? Él respondió: Yo soy Juan, el último de los profetas, el que enderecé los caminos del Hijo de Dios y prediqué penitencia al pueblo para remisión de los pecados... Y oí asimismo la voz de Dios Padre que decía así: Éste es mi Hijo, el amado, en quién me he complacido. $Y$ por eso mismo me envió también a vosotros, para anunciaros la llegada del Hijo de Dios unigénito a este lugar, a fin de que quien crea en Él, sea salvo y quien no crea, sea condenado"; SANTOS OtERO 1984: 444-445); en cambio, en la versión latina, Juan está dentro del limbo al lado de Adán y de Isaías, vestido de anacoreta, considerado profeta y fundador de la orden hospitalaria: «Entonces apareció a su lado otro personaje con aspecto de anacoreta. $Y$ le preguntaron diciendo: ¿Quién eres tú, que llevas tales señales en tu cuerpo? y él respondió con entereza: Yo soy Juan el Bautista, la voz y el profeta del Altísimo... Yo señalé con mi dedo a los jerosolimitanos y glorifiqué al cor- 
dero del Señor y al Hijo de Dios... Yo mismo recibi también promesa suya de que ha de bajar a los infiernos" (Ibidem 465). Según este escrito san Juan tiene una función doble: de mensajero y de guía para conseguir la salvación. Dicha duplicidad también se manifiesta en su relación con el infierno, pues como enviado de Dios está fuera, y como conductor de las ánimas en pena está dentro. Esta ambigüedad se evidencia en las representaciones plásticas, ya que algunas veces aparece detrás de Cristo, colaborando en la liberación, y en otras, espera la llegada del Señor junto con el resto de almas buenas. La profesora M. Guardia (1986: 104, n. 48), dice que a partir del siglo xI la escena de la anástasis empieza a complicarse en número de personajes y que a finales de esta centuria se reconoce a Juan Bautista dentro del infierno, encabezando el grupo de los Reyes. Si el personaje que hay en nuestras pinturas puede identificarse con el Bautista, creemos que se habria utilizado la versión latina del apócrifo, pues se halla en el interior del purgatorio, aunque a punto de salir.

San Pedro Pascual, recoge la idea de la relación entre san Juan y el infierno o el purgatorio. En una parte de su tratado reproduce la História de Sant Llàtzer; en la que se explica que cuando Lázaro murió fue transportado por los ángeles al limbo, donde estaban los patriarcas, y allí se encontró con san Juan: «E mentre Jesu Christ venia Angels portavan la anima de Llàtzer al lim dels Sancts Pares, e quan la veneyta se ve desamparada per l'Angel vas mentre a cercar lo loch on staven los Sancts Pares i Sanctes; e cercant troba la anima de Sanct Joan Baptista, e per ço com noy havia gaire coneixença nos feren gayre e en aço que parlaren ells se adomesticaren e fou gran amistat de Jesu Christ, si be Llatzer hi havia estat be poch, e hagueren moltes noves i rahons" (ARMENGOL 1906: 5). En otros escritos de este teólogo se da mucha importancia al Bautista, por ejemplo en Lo segon «Agnus Dei». «E com Sanct Joan vee part de la passio, e com Joan lo sanct babtisme de Jesu Christ», se establece un diálogo entre Cristo y el santo, en el cual éste último le pide que le prediga cómo será su muerte y si podrá convertirse en su mensajero cuando llegue a los infiernos, y Cristo le responde asi: "Ans de la mia passio vos pasarets daquesta vida per corona de martiri, e, a gran companya dangels, jous fare portar en lo loch, on nostres cars amichs los Sancts Pares son, e vos los denunciareu yols alegrare, els traure daquell loch tant tenebros, els metre en plena gloria mia, la qual no haura $\mathrm{fi}$, la qual tan han desitjada; e alegrar los ets ço que avets vist presencialment axi per la revelacio com per visio" (Ibidem 80 ).

En el Misterio de santa Genoveva, texto visionario francés del siglo $x v$, en el interior del infierno se puede reconocer a Adán y Eva, Juan Bautista y Noé. 
Aunque en los textos Juan tiene esta doble acepción, en el campo plástico su papel queda reducido al de mensajero, situado fuera del infierno y, normalmente, detrás de Cristo. La participación de este santo en el descendimiento se da frecuentemente en el arte oriental, básicamente en el bizantino, y en cambio, conocemos pocos ejemplos en el arte occidental. En uno de los mosaicos de la iglesia griega de Daphni Juan Bautista, situado detrás de Cristo, levanta dos dedos de la mano como simbolo de anuncio de la buena nueva (fórmula propia de la iconografía oriental). Esta misma composición se repite en la Anástasis del muro occidental de la catedral de Torcello (GuARDIA 1986: figs. 8 y 11). Hasta estos momentos desconocemos cualquier paralelo en el que san Juan esté situado en el interior del infierno o del purgatorio.

La imagen específica del Bautista es la de un hombre alto y delgado, oscuro de piel, con barba negra y cabellos despeinados. Su vestimenta cambia con el paso del tiempo: en un primer momento, lleva las ropas típicas de los apóstoles, después se cubre con un simple palio y al final, a partir del siglo XIV, con una túnica corta de piel de camello. En el arte occidental, sus atributos especificos son el Agnus Dei y la concha bautismal (Ferrando Roig 1950: 156). En la iconografía oriental va vestido de anacoreta (en algunos casos sólo se cubre con su propio pelo), normalmente tiene la mano derecha levantada y con dos dedos hace la señal de aviso. Uno de sus atributos básicos es la cruz de caña. Asi pues, creemos que este personaje anónimo tiene dos atributos que pertenecen a la iconografia de san Juan Bautista: la cruz y el gesto de los dedos. Sin embargo, no conocemos ejemplos en los que el santo aparezca desnudo (de todas maneras, la desnudez de los personajes sagrados está justificada en la escena de la Anastasis ya que están condenados temporalmente, además en algunas representaciones de Descendimiento, Adán y Eva aparecen desnudos).

\section{Aviso a los fieles contra los peligros de la muerte repentina}

En el sector de poniente del muro norte de la nave hay representadas dos escenas, la de la derecha hace referencia a un episodio de la vida de san Cristóbal (la del momento en que el santo ayuda a Cristo a cruzar un río caudaloso) y la de la izquierda, más dificil de interpretar. El profesor Sureda (que fue el primero en identificar la escena), cree que la elección de este santo no es arbitraria sino que está en función de un programa de exaltación de los santos protectores contra la peste, que se desarrolla en las pinturas del brazo norte de la capilla-transepto (SUREDA 1981: 369 y 375). Nosotros opinamos que la comparecencia del santo es 
consecuencia de lo que representa su figura y que, tanto por proximidad topográfica, como iconográfica y cronológica, se ha de relacionar con el programa desarrollado en la zona occidental de la iglesia.

Uno de los pasajes más conocidos de la hagiografía de san Cristóbal es el transporte de Cristo sobre sus hombros para cruzar un río muy caudaloso. El tema fue difundido ampliamente, a partir del siglo XIII con el relato de la Leyenda Dorada (JACOBO DE LA VORAGINE 1982, I: 407). Es un episodio que aparece en diversas pinturas del gótico lineal catalán. Además de los ejemplos ya conocidos, como el frontal del altar del Museo Nacional de Arte de Cataluña y las pinturas murales de la iglesia de Sant Pau de Casserres (Barcelona), aportamos uno nuevo, aparecido hace unos años y que estamos estudiando actualmente. Se trata de los frescos de la iglesia de Sant Cristófol de la Castanya (Barcelona), descubiertos el año 1986 en el curso de una restauración llevada a cabo por el servicio de Patrimonio Arquitectónico de la Diputación de Barcelona, y posteriormente trasladados al Museo Episcopal de Vic (Barcelona).

En Sant Valentí, la composición se encuentra en bastante mal estado y el santo es poco visible, ya que simplemente queda una pequeña parte de la cabeza, en cambio, la figura de Cristo está prácticamente entera (figs. 4,7). Esta última presenta una tipologia diferente a la descrita en la Leyenda Dorada, ya que no aparece como niño sino como adulto. La posición y la actitud del personaje recuerdan de cerca a los pantocrátores románicos, aunque lleva un atributo que permite identificarlo con el Salvator Mundi: la bola tripartita que sostiene con la mano izquierda, símbolo de las tres partes de la tierra (Europa, Asia y África), además de bendecir con la derecha (LLOMPART 1977, 2: 109-112). Según L. Réau (1958: 308), la representación de Cristo como hombre pertenece a los ejemplos más antiguos de esta fórmula ya que en el siglo XIV se substituye por un niño. Los paralelos iconográficos más interesantes (ya indicados por Sureda), son los de la Tour Ferrade de Pernes y los de la iglesia tarraconense de Peralta. A partir de los restos conservados, podemos observar que la figura del santo tendria que haber sido de dimensiones considerables pues ocupa toda la parte alta de la pared, y además, Cristóbal muchas veces tiene la altura de un gigante. Parece ser que este santo tenia unas virtudes profilácticas fenomenales, ya que bastaba haberlo visto una vez al dia para evitar la muerte, y por ello su imagen se situaba en las fachadas y puertas de las iglesias (REAU 1958: 306). En la iglesia de la Asunción de Olleta, en Navarra, se conserva un san Cristóbal enorme, situado en el mismo lugar que en Sant Valenti, es decir, en la pared norte, justo delante de la puerta (LACARRA 1974: 348), de tal forma que era lo primero que veian los fieles cuando entraban en el edificio. 
Si bien es cierto que san Cristóbal era uno de los santos invocados contra la peste, junto con san Antonio Abad, san Sebastián y san Roque, en un principio su popularidad radicaba en que protegia de la muerte sin confesión (igual que santa Bárbara). Como consecuencia de esta primera acepción también evitará las enfermedades contagiosas (REAU 1958: 305306). Guillermo de Auvergne en De Universo, obra de la segunda mitad del siglo XIII, defiende que quienes mueren súbitamente no tienen tiempo de confesar sus pecados y por tanto necesitan purificarse antes de entrar en el paraiso. Sigue diciendo que el purgatorio es un lugar muy poblado, situado entre la muerte y la resurrección, donde las almas continuan con la penitencia terrenal y así expian sus culpas mediante castigos (LE GoFF 1989: 279-280).

En otros escritos anteriores también aparecen consideraciones sobre el purgatorio, donde se dice que las almas esperan la misericordia divina y que mientras tanto han de hacer penitencia y padecer los suplicios pertinentes. En la quinta redacción de la Visio Sancti Pauli, el purgatorio está situado sobre el infierno, y en este estadio superior se castiga a unas almas concretas: "Superius infernus est ingnis purgatorii, ubi sunt anime que expectant misericordiam dei; et ibi penitentiam agunt, ibi purgantur, et ibi sustinent penam per uginti ut triginta, uel per centum annos uel usque ad diem iudicii» (SILVERSteIn 1935: 197). En una de las obras de san Pedro Pascual aparecen aseveraciones similares: «En lo ters infern es pena de foch... e aquell loch es apellat Purgatori, e en aquell avallen tots aquells qui en a quet mon, no han cumplida la penitencia de llurs pecats... e aquells devallen en aquest loch per purgar lurs pecats, dels quals no han feta penitencia, e apres de quet purgatori, van en la gloria celestial» (ARMENGol 1907, II: 185).

Estas referencias literarias, sobre todo las reflexiones de Guillermo de Auvergne, permiten establecer un programa iconográfico para las pinturas de poniente. La clave interpretativa está en la figura de Cristóbal, ya que entendemos la presencia de este santo como un símbolo de aviso a los fieles contra los peligros de la muerte súbita, evidenciados en los muros oeste y sur. Todo el conjunto occidental intenta destacar la importancia que tiene la penitencia cotidiana para evitar las torturas del purgatorio y conseguir la salvación (significado de la figura que hemos interpretado como san Juan). Esta hipótesis interpretativa puede sustentarse en una serie de paralelos iconográficos indirectos, pero con significados similares. En los frescos de la iglesia francesa de Saint Genest de Lavardin, san Cristóbal forma parte de un ciclo en el que se describe el infierno y el paraiso (Deschamps, Thibout 1963: 158-159). En las pinturas de la iglesia de Peralta, aparece asociado a escenas de pecado y de salvación. Sureda opina (1986: 109) que los cinco fragmentos conservados contienen 
temas aislados: una escena de juicio (Dominus rodeado del tetramorfos), una de pecado (Adán y Eva avergonzados de su pecado, debajo del árbol), una de salvación (de la humanidad, representada por la crucifixión) $y$, finalmente, san Cristóbal con el Niño en los hombros. Asi pues, el santo también está relacionado con la salvación de los hombres, incluso de los pecadores, gracias a la muerte de Cristo.

De todas maneras, la elección de Cristóbal también podría estar vinculada a la orden de los hospitalarios, como en el caso de la Tour Ferrade de Pernes (edificio propiedad de esta orden y decorado con unas pinturas murales encargadas por un senescal), en las que aparece san Critóbal y una escena de combate entre Guillermo de Orange y un gigante, que podría interpretarse como una lucha entre las fuerzas del mal y del bien y el triunfo de estas últimas (Deschamps, Thibout 1963: 234; RoQues 1961: 139).

La escena siguiente se conserva en peor estado (figs. 4,7 ) y sus únicos elementos identificables son un cuervo, posiblemente situado encima de una cabeza, y una mano. El profesor Sureda (1989: 370-371) cree que el cuervo sólo puede relacionarse con dos santos, Vicente y Antonio Abad, y se decanta por el segundo ya que se trata de un santo invocado contra la peste, por lo que formaria parte del programa de exaltación de santos protectores de esta epidemia que, según este autor, se desarrolla en los muros de la capilla-transepto de esta iglesia. Esta interpretación nos parece sugerente, ya que hemos identificado dicho santo en las pinturas del nordeste del mismo edificio.

Esta composición también podria pertenecer a la vida de san Valentín, a partir del tema reproducido en un capitel del claustro del monasterio de Sant Benet de Bages (Barcelona). En dicho capitel (el número trece de la galeria de levante) aparece un hombre vestido con túnica, con los brazos levantados, hacia el que se dirige un pájaro; a su lado hay otro personaje arrodillado. Según el doctor Junyent, en este cenobio se habrian depositado las reliquias de san Valentin y, por tanto, el tema del capitel pertenecería a una escena de su vida. Si esta identificación fuera cierta, podría ser interesante ya que precisamente el santo titular de nuestra iglesia es Valentín, no obstante, no ha podido probarse que sus reliquias hubiesen estado alguna vez en Sant Benet. La opinión del profesor Barral (Ibidem 1984: 428-438) es que se trata de una escena de la vida de san Benito, a quien está dedicado el monasterio. Estos fragmentos pictóricos también podrian atañer a un episodio de la vida de san Francisco de Asís, pues la mano situada delante del cuervo presenta un orificio en el carpo, que tal vez reproduzca una llaga, atributo especifico de dicho santo. Además, uno de los actos más destacados de la hagiografia de Francisco es la 
predicación a los pájaros. En la iglesia de san Esteban de Sos del Rey Católico (Zaragoza), hay una composición en la que interviene un santo rezando a unas aves situadas sobre un árbol, y una de ellas se posa en la cabeza del personaje. Según F. Abad Ríos (1971: 20-21), podria tratarse de un pasaje de la vida del santo de Asis. En la iglesia de Saint Genest de Lavardin, aparecen asociados san Francisco y san Cristóbal en un ciclo dedicado a escenas de infierno y paraiso. En la capilla Chalard de la iglesia de Saint Genies de Dordoña, los dos santos están juntos (DESCHAMPS, ThiBOUt 1963: 158-159).

Debido a la precariedad de lo conservado, no podemos llegar a ninguna conclusión fiable. De todas maneras, creemos que una de las interpretaciones más sugerentes es la posible relación con san Francisco de Asís, tanto por la afinidad con san Cristóbal como por los paralelos iconográficos establecidos (sobre todo los franceses).

\section{EL PROGRAMA ICONOGRÁFICO DEL NORDESTE}

El profesor Sureda (1981: 375), opina que en esta capilla se exalta a unos santos que tienen como virtud la protección de la peste. Sin embargo, ni san Andrés, ni santa Catalina de Alejandria, ni san Esteban -que según este mismo autor, pueden ser algunos de los nombres de los personajes representados en el muro este- evitan dicha epidemia. Asi como tampoco san Martín que está representado en la pared norte de la misma estancia. Aunque nos falta información para poder establecer un programa concreto, pensamos que la elección de los santos podria estar vinculada a la orden del Hospital, con la finalidad de propagar los principios humanitarios que regían dicha comunidad.

\section{San Martín ofrece su capa a un pobre}

Esta escena se encuentra en el muro norte (figs. 8, 10) y trata del episodio en el que san Martín comparte su capa con un pobre (SuREDA 1981: 371) siguiendo una fórmula iconográfica esteriotipada. San Vicente Ferrer (1977: 251-257) utiliza este acto para demostrar la caridad de san Martín para con los pobres: «E finalment vench sent Martí de Tours e veu to pobre despullat e dix: "O llas, e si yo jaquia axi aquest pobre, que'm dirie mon senyor Jesuschrist, quan la mia ànima exirà de aquest món? Ell guardà si tenie diners, e non poch haver axi, perquè estava armat e no havia sinó lo mantó. E cridà lo pobre e dix: no tinch sinó aquest mantó, 
mas nec mihi nec tibi, sed dividatur. E tragué la spasa e parti'l, e lo pobre abrigalà'l e vasse'n alegre"".

El que fuera obispo de Tours, era noble y militar por tradición familiar. En función de estos privilegios se convirtió en el primero de los santos caballeros. Cumplió con los tres votos ordinarios, además de luchar fervientemente contra la herejía y proteger a los pobres. Asi pues, tanto por su origen, como por su profesión y virtudes personales pudo ser considerado como modelo por los caballeros de la orden del Hospital de San Juan de Jerusalén. Los miembros de dicha comunidad tenian que demostrar su nobleza de linaje y pureza de sangre, se regían por los principios religioso y militar, y además de los votos ordinarios tenian que seguir otros que, según Lacroix (1877: 193), eran los siguientes: Ia tranquilidad espiritual, vivir sin maldad, llorar los pecados, humillarse ante las injusticias, ser justo, misericordioso, sincero, limpio de corazón y sufrir la persecución. Estas obligaciones coinciden a grandes rasgos, con las virtudes de Martín propuestas por san Vicente Ferrer (caridad con los pobres, fidelidad divina, humildad personal, pobreza, dignidad personal, benignidad $y$ estabilidad final).

\section{Conjunto de santos}

La identificación de los personajes del muro este es una tarea complicada debido a que ha desaparecido la mayoria de las inscripciones con los nombres de los santos. Al estar claramente identificados, no necesitaban de atributos específicos y por eso sólo llevan el libro sagrado y la palma de martirio. Ni la vestimenta, ni el carácter fisiológico de las imágenes pueden ayudarnos a aportar nombres definitivos.

El único que hemos podido identificar con cierta precisión, es el que está representado en el último compartimento del registro superior (figs. 9, 11), cuyo nombre es san Antonio. Sureda (1981: 372-373) creia que se trataba de san Andrés, pues lleva una cruz colgada del brazo. Sin embargo, no se trata de una cruz en aspa sino en forma de tau; no va vestido como los apóstoles y en cambio está tonsurado. Nosotros creemos que se trata de san Antonio Abad, porque viste hábito oscuro (negro o marrón) con capucha, tiene barba y lleva colgada la cruz tau, que es uno de los atributos específicos de este santo, incluso parece que sostiene una paloma entre las manos (se ve con mucha dificultad). San Antonio era anacoreta, fundador de la orden de los antoninos, protector contra la muerte repentina, las enfermedades contagiosas y defensor de los animales domésticos. Paralelamente fue considerado un luchador infatigable contra las tentaciones del demonio. 
Según el profesor Riu, el nombre del santo que aparece a la derecha de san Antonio podria transcribirse como san Benito o san Bernardo (figs. 9, 11). Si fuera san Benito, fundador de la orden benedictina, tendría que llevar ropas negras y, en cambio, va vestido de blanco. Quizá sea Bernardo de Claraval, fundador de la orden cisterciense, ya que además de coincidir en el color del hábito, lleva una amplia tonsura.

La santa del registro inferior ha sido identificada como santa Catalina de Alejandria (figs. 9, 11). El profesor Sureda se basa en que lleva corona y palma de mártir, no obstante, estos dos atributos son muy generales y no ofrecen una información precisa. En la inscripción de la cartela parece que se puede leer una abreviatura de Isabel (según M. Riu). Dicha santa va vestida con ropas de casada. Tal vez sea santa Isabel de Hungria, noble y unida en matrimonio desde los cuatro años, la cual formó parte de la tercera orden franciscana y fundó un hospital para atender a los pobres, enfermos y leprosos.

Por lo que respecta al resto de los santos sólo podemos decir que todos presentan tonsura y que la mayoria sostiene las Sagradas Escrituras, lo cual nos hace suponer que podrian ser fundadores de órdenes religiosas (figs. 9, 11). El primero del registro superior recuerda la imagen de san Pedro mártir (si lo comparamos con el retablo dedicado a este santo del Museo Nacional de Arte de Cataluña, aunque sólo sea tipológicamente ya que el color del hábito no se corresponde con el de los dominicos). El segundo santo del mismo registro parece tener más importancia que el resto, ya que es el único que está situado de frente y los demás parecen observarlo. Se ha supuesto que se trataba de san Esteban (SuREDa 1981: 373-374) debido al enrejado que le sirve de fondo, que reproduciría la parrilla en la que fue asado. El reticulado es un motivo ornamental usado en muchas ocasiones, incluso en este mismo conjunto se utiliza para decorar el compartimento de la supuesta santa Isabel.

Relacionar todos estos santos entre sí y vincularlos con la escena de san Martín, resulta dificil, ya que la escasa información de que disponemos no nos permite ver con claridad cual era el objetivo final de este ciclo. Tanto Martín como Antonio Abad e Isabel de Hungria, son santos que protegen a los pobres y cuidan a los enfermos. Uno de los elementos básicos de la reforma introducida por san Bernardo es el retorno a la pobreza. La lucha y posterior victoria contra el demonio nos podria servir para relacionar san Martin y san Antonio, que a la vez se pueden agrupar por proteger los animales domésticos. Finalmente, opinamos que tal vez la elección de los santos destacaría las principales atribuciones de la orden hospitalaria, es decir, el cuidado y protección de los pobres y enfer- 
mos (ambas actividades parecen estar presentes en las vidas de algunos de los santos de esta capilla).

\section{ANÁLISIS FORMAL}

Aunque estilisticamente estos murales pertenezcan al gótico lineal, observamos ciertas diferencias de tratamiento entre las pinturas de poniente y las del nordeste. Esta distinción también coincide con la presencia de dos programas iconográficos independientes.

Las pinturas de poniente (figs. 2, 3, 4) siguen unos parámetros formales similares aunque con variaciones. Las composiciones son bidimensionales con fondos diversos: en el muro sur hay llamas rojizas, en el del oeste predomina el color oscuro, y el del norte está recubierto por una capa de rojo pálido salpicada de motivos florales. La gama cromática queda reducida al marrón, rojo, amarillo y gris. Todos los personajes, animales y objetos están contorneados por una línea gruesa que, a la vez, enmarca los colores aplicados en tintas planas. Las escenas están colocadas una al lado de la otra sin separación fisica, sólo se diferencian por un cambio temático.

Tanto en el muro sur como en el norte existe un tratamiento formal muy semejante. En los dos casos el linealismo es evidente pues la linea además de servir para perfilar las figuras, en algunos casos es el único elemento que les da forma. La tipología de los rostros es la misma. El único elemento ornamental del conjunto aparece en la cenefa que enmarca la escena de san Cristóbal y el Niño. Es un motivo llamado de acicate, sobre todo usado en la cerámica y con una larga tradición en el arte árabe (posteriormente es recuperado en la cerámica valenciana de Paterna y de Manises, Martínez Caviro 1982: 115). De estas características formales podemos deducir que se trata de una pintura ejecutada con criterios que todavia tienen que ver con la estética románica, este hecho también se evidencia en el tratamiento geométrico del cuerpo de los condenados, y en el Cristo situado sobre los hombros de Cristóbal que sigue la tipologia de los pantocrátores románicos.

Aunque las figuras del muro oeste se parezcan bastante a las anteriores, se pueden apreciar ciertos cambios morfológicos: presentan un canon más alargado, el cuerpo se resigue con una línea sin que aparezcan los compartimentos internos, la cabeza es más ovoide y los irazos del rostro más realistas. Por tanto nos parecen más góticas que las anterio- 
res, tal vez debido a que serían de un pintor, del mismo taller, pero con unos conocimientos formales más afines al nuevo estilo.

Uno de los paralelos formales más claros es el conjunto mural de la Tour Ferrade de Pernes. La escena de san Cristóbal nos sirve para comparar las dos decoraciones y ver que tanto la composición como la configuración y actitudes de los personajes, se aproximan bastante. Se trata de figuras absolutamente planas, con rostros de forma oval, ojos almendrados, cejas unidas a la nariz y boca pequeña. El Cristo situado encima de san Cristóbal, viste de la misma manera y ambos bendicen con la derecha y sostienen la bola del mundo con la izquierda. Sureda (1981: 376377) establece como paralelo formal la decoración de la iglesia de Peralta (Tarragona), que a la vez se asemeja a la de Pernes, basándose en la comparación de las escenas dedicadas a san Cristóbal y en el árbol, que aparece tanto en Sant Valentí como en el templo tarraconense (respectivamente, en el muro oeste y en la escena de pecado original). Es evidente que se trata de dos paralelos muy interesantes para los frescos norte y sur.

En cambio, para el conjunto oeste proponemos como paralelo la decoración de la iglesia francesa de Asnières-sur-Vègre, que ya hemos citado otras veces. Si comparamos el ánima que se salva en nuestras pinturas (posible Juan Bautista) y las figuras que aparecen en la escena de la anástasis de los murales franceses, apreciamos que presentan un tratamiento formal similar. En ambos casos, las figuras se contornean con una gruesa línea negra, son de canon alargado, poseen el mismo tipo anatómico y los rostros se aparecen, asi como también sus posiciones y actitudes respectivas.

Los frescos del nordeste son diferentes (figs. 8, 9) ya que, aun tratándose de composiciones planas, se insinúan ciertos intentos de romper con la bidimensionalidad (algunos santos aparecen de perfil y los libros sagrados están dibujados en diagonal). El fondo aparece recubierto de un color uniforme, alternándose el rojo y el azul, y sólo en dos casos se ha sustituido por una reticula (de este esquema ornamental encontramos muchos paralelos en la pintura mural y miniatura del gótico lineal). La composición se basa en una sucesión de compartimentos (posiblemente inspirada en los tejidos, GaLLEGo 1972: 131-161) separados mediante una orla de motivos vegetales. El encuadre de dichas estructuras rectangulares, a base de una estructura arquitectónica (apoyada en dos columnitas que sostienen un arco trilobulado, cerrado por una cubierta a dos aguas rematada por florones), es un sistema frecuente tanto en la pintura mural, como en la miniatura y la escultura del primer gótico. En la ejecución de los santos predomina el linealismo que configura los cuerpos y los plie- 
gues de los ropajes, aunque con intención de conseguir más volumen. Hay un interés por individualizar los rostros y por acrecentar el realismo, que se evidencia en la precisión de los detalles (dibujo de las uñas de las manos). Los colores son más cálidos y brillantes, con abundancia de rojos, azules y ocres.

Los paralelos formales más próximos podrian ser, entre otros, el frontal de altar de Sant Cebrià de Cabanyes (Museo Episcopal de Vic, Barcelona), básicamente por el desarrollo compositivo, por el encuadre y por la orla decorativa.

En el triptico-relicario de la catedral de Tortosa, el fondo de las escenas es reticulado y las representaciones se encuadran mediante arcos trilobulados culminados por florones. Apreciamos cierta semejanza compositiva con el mural dedicado a santo Tomás de la iglesia de San Miguel de Daroca (Zaragoza), dividido en dos registros, organizados estructuras arquitectónicas trilobuladas que contienen los santos. Las figuras se hallan de perfil, a excepción de la escena de la duda de santo Tomás, que está de frente. En nuestros murales se repite el mismo esquema, incluso uno de los santos aparece en posición frontal.

Como conclusión creemos que estas pinturas podrian haber sido ejecutadas por un taller local influido por los de Tarragona, que empiezan a tener importancia durante la primera mitad del siglo XIV (GUDIOL, ALCOLEA 1986: 31-32). Es evidente que los frescos de Sant Valenti, por lo que se refiere al tratamiento formal no pueden atribuirse a un taller importante, debido a su poca calidad técnica que contrasta con la riqueza iconográfica.

\section{CRONOLOGIA}

El profesor Sureda, después de efectuar un análisis riguroso, llega a la conclusión de que estas pinturas pertenecen al protogótico avanzado, y que pueden fecharse entre 1350 y 1360 (1981: 380). La justificación de estas datas se basa en los dos programas iconográficos propuestos: el de la visión infernal y el de la exaltación de los santos protectores contra la peste. Respecto a las razones aportadas habria que señalar que, por una parte, el tema de la visión escatológica es muy antiguo, con ejemplos en la miniatura de los Beatus y, por otra parte, no consideramos plenamente confirmada la relación entre los santos y la peste (supra: V. 2). En función del estudio de una serie de aspectos, creemos que la cronología 
de este conjunto mural no es unitaria pues se pueden dividir en dos momentos pictóricos ligeramente diferenciados.

La excavación arqueológica llevada a cabo en este edificio por los técnicos del Servicio del Patrimonio Arquitectónico de la Diputación de Barcelona, puso de manifiesto de forma inequívoca que la iglesia fue construida hacia el último tercio del siglo xIII (LOPEZ, Fierro, Clua 1990: 89), descubrimiento muy interesante ya que anteriormente siempre se habia creido que la primera fase constructiva pertenecia al románico del siglo XII. Es evidente que este retraso en las fechas concuerda bastante bien con la datación de las pinturas, concretamente con las de poniente.

Por lo que respecta a las fuentes documentales, no hemos encontrado referencias directas a los murales. De todas formas, sabemos que una de las primeras encomiendas de la orden de San Juan de Jerusalén se estableció en Les Cabanyes, y que en 1306 esta comunidad se trasladó a Vilafranca del Penedès. Hay una serie de indicios que nos permiten aventurar que algún miembro de dicha comunidad pudo encargar los frescos. Era muy corriente que los caballeros de san Juan, contratasen artistas para decorar sus propiedades (DEschamps, ThIBOUT 1963: 234), la Tour Ferrade de Pernes y el castillo de Alcañiz (Teruel), son dos ejemplos. Además, en algunos documentos queda patente el interés que tenian por los ornamentos de sus armas: en 1295, Arnau de Terrassa, pintor, vende a un caballero de la orden de san Juan una silla de montar, un escudo, una coraza y otras piezas decorativas; en 1308, Pere de Olivera, pintor de Barcelona, firma un recibo por las armas que habia hecho para el Maestre de la orden de san Juan de Jerusalén (Gudiol, Alcolea 1986). Una de las aportaciones más elocuentes de la relación entre nuestras pinturas y los jerosolimitanos es la posible identificación del alma que sale del purgatorio (situado en el extremo izquierdo del muro oeste) con san Juan Bautista (supra, IV. 2), considerado el fundador espiritual de la orden. La elección de san Cristóbal, también en el programa de poniente, es usual en las decoraciones murales encargadas por los caballeros hospitalarios (recordemos la Tour Ferrade de Pernes). Finalmente, se puede decir que en las pinturas del nordeste aparece san Martín de Tours, máximo representante de santo caballero y de origen noble, y por tanto modelo ejemplar para los miembros de dicha orden.

La cronología de las pinturas también está en función del tratamiento formal. Ya hemos visto como las de poniente tienen ciertas reminiscencias románicas y parecen pertenecer a una primera fase decorativa. Los paralelos de la Tour Ferrade de Pernes, fechada en el último cuarto del siglo XIII (Roques 1961: 139; Deschamps, Thibout 1963: 234), y de la iglesia de Asnieres-sur-Vègre, datada entre la primera mitad del XIII (PRÉ 1956: 
1) y mediados de la misma centuria (Deschamps, ThiBout 1963: 102-103), podrian llevarnos a unas fechas próximas para la decoración estudiada. Sin embargo, también hay que tener en cuenta las pinturas más tardias de la iglesia de Peralta (hacia el segundo cuarto del siglo XIV. SuREDA 1986: 109). La iconografia, tampoco es muy indicativa ya que las fuentes literarias usadas empiezan en los siglos $110 \mathrm{II}$, con el apócrifo paulino, y finalizan en el siglo XVII, con los últimos relatos visionarios. Según A. Pacheco (1973: 17-18), en el caso de Cataluña todos estos textos escatológicos empezaron a traducirse y a tener una gran difusión durante el siglo XIV.

Las pinturas del nordeste tienen un tratamiento formal claramente gótico. Los paralelos establecidos se basan, sobre todo, en el esquema de organización compositiva muy frecuente en esa época. El mural del refectorio de la catedral de Pamplona, obra de Juan Oliver, está fechado en 1330 (LACARRA 1974: 155-189), la decoración dedicada a santo Tomás de San Miguel de Daroca (Gudiol 1971: 72) y el frontal de Sant Cebrià de Cabanyes (Museo Episcopal de Vic, Barcelona, Sureda 1986: 114) son de la primera mitad del xIV. Sabemos que las representaciones de santos empiezan a difundirse a partir del siglo xIII en pintura sobre madera, y a comienzos del xiv en la mural.

En función de todas las consideraciones aportadas, llegamos a la conclusión de que la fecha aproximada para las pinturas de poniente sería el último tercio del siglo xill, siendo contemporáneas a la construcción del edificio; en cambio, el conjunto del nordeste sería un tanto más avanzado, posiblemente de hacia mediados del siglo xIV.

\section{BIBLIOGRAFIA}

Asin Palacios, M. (1944 y 1966): La escatologia musulmana en la Divina Comedia. Madrid.

Armengol Valenzuela, P. (1906): Obras de San Pedro Pascual, Mártir, I. Roma.

- (1907): II y III.

- (1908): IV.

Baltrusaltis, J. (1960): Le gothique fantastique (Reveils et Prodiges). Paris.

Barral I Altet, X. (1984): “Sant Benet de Bages. El Claustre», Catalunya Romànica. El Bages. Barcelona, XI: 428-438.

Batlle y Huguet, P. (1949): "Las pinturas murales de Peralta (Tarragona)", Boletin Arqueológico de Tarragona, XLIX: 177-183.

- (1952): "Las pinturas góticas de la catedral de Tarragona y su Museo Diocesano", Boletín Arqueológico de Tarragona, Lll: 197-218.

BENEDEIT (1983): El Viaje de San Brandán. Madrid.

Champeaux, G.; Sterckx, D. S. (1984): Introducción a los simbolos, 7. Madrid.

Churruca, M. (1939): Influjo oriental en los temas iconográficos de la miniatura española. Madrid. 
Delclaux, F. (1973): Imágenes de la Virgen en los códices medievales de España. Madrid.

Deschamps, P.; Thiвout, M. (1963): La peinture murale en France au début de l'èpoque gothique. París.

Ferrando Roig, J. (1950): Iconografia de los santos. Barcelona.

GALLEGO, J. (1972): “Los compartimentos tabicados, una organización abstracta para la pintura figurativa", Revista de Occidente, 110: 131-161.

GuardiA, M. (1986): "Una obra bizantina de Ciudad Real y el tema de la Anástasis», D'Art, 12: $89-111$

Gudiol, J. (1971): La pintura medieval en Aragón. Zaragoza.

Gudiol, J.; ALCOLEA, S. (1986): Pintura gótica catalana. Barcelona.

Lacarra Ducay, M. C. (1974): Aportación al Estudio de la Pintura Mural Gótica en Navarra. Pamplona.

LACRoIX, P. (1877): Vie militaire et religieuse au Moyen Age et a l'èpoque de la Renaissance. Paris.

LaUer, PH. (1927): Les enluminures romanes de la Bibliothèque Nationale. París.

LE GoFf, J. (1989): El nacimiento del Purgatorio. Madrid.

Lópz, A.; Fierro, J. y Clua, M. (1990): “Resultats de l'excavació duta a terme a l'església de Sant Valenti de Les Cabanyes", Miscellània Penedesenca, XIV: 71-100.

LLOMPART, G. (1970): “Aspectos populares del purgatorio medieval», Revista de Dialectologia y Tradiciones Populares, 26: 253-274.

- (1977): La pintura medieval mallorquina. Su entorno cultural y su iconografia, 2. Palma de Mallorca.

LLORACH I SANTIS, S. (1978): “El Penedès durant el periode romànic". Miscellània Pedesenca, I: $65-88$.

MALE, E. (1925): L'art religieux de la fin du Moyen Åge en France. Paris.

- (1953): L'art religieux du XIIIe siècle en France. Paris.

Mariño, B. (1989): “Sicut in terra et in inferno. La portada del Juicio en Santa Maria de Tudela", Archivo Español de Arte, 246: 157-168.

Melero Moneo, M. (1984): “Los textos musulmanes y la puerta del Juicio de Tudela (Navarra)", Actas del V Congreso Español de Historia del Arte, I: 203-215. Barcelona.

Martinez Caviró, B. (1982): La Loza Dorada. Madrid.

Maury, J. (1905): Reseña de las órdenes religiosas. Disciplina y culto. Barcelona.

Mesuret, R. (1967): Les peintures murales du sud-oeste de la France. Paris.

MeYER, P. (1895): "La descente de Saint-Paul au enfer", Romania, XXIV: 357-375.

Miquel y Planas, R. (1914): Llegendes de l'altre vida. Barcelona.

- (1917): Històries de l'altre temps. X. Viatge al purgatori de Sant Patrici; Visions de Tundal $i$ de Trictelm; Viatge de'n Pere Portes. Barcelona.

OWEN, D. R. (1970): The Vision of Hell. Nueva York-Edimburgo.

PACHECO, A. (1973): Viatges de l'altre món. Dos relats dels segles xIv i xvII. Barcelona.

Réaus, L. (1956): Iconographie de l'art chrétien. Iconographie de la Bible. I. Ancien Testament, II. Paris.

- (1957): Iconographie de l'art chrétien. Iconographie de la Bible. II. Nouveau Testament, III. Paris.

- (1959): Iconographie de l'art chrétien. Iconographie des saints, III. Paris.

PRÉ, M. (1953): «Découvertes récentes de peintures murales des XIIle et XIVe siècles dans Le Maine", Gazette des Beaux Arts, XLII: 90-96.

- (1956): "Dernières découvertes de peintures murales a l'église du Asnières-sur-Vègre", Gazette des Beaux Arts, XLVIII: 1-10.

SAN Gregorio (1968): Diálogos, edición a cargo de A. J. Soberans. Barcelona.

Santos Otero, A. (1984): Los Evangelios Apócrifos. Madrid.

Silverstein, TH. (1935): Studies and Documents IV. Visio Sancti Pauli. The History of Apocalipsis latin together nine texts. Londres.

SuREDA I Pons, J. (1977): El Gótic Català. I. Pintura. Barcelona. 
Los frescos góticos lineales de la iglesia de Sant Valentí de les Cabanyes...

- 1981: "Les pintures murals de Sant Valenti de Les Cabanyes", Quaderns d'Estudis Medievals, 6: 364-381.

- (1986): “Fragments de la decoració mural de l'església de Peralta», Thesaurus. Estudis. Barcelona, 109-110.

VILLENUEVE, R. (1957): Le diable dans l'art. Paris.

VILLER, M. (1950): Dictionaire de spiritualité ascetique et mystique, doctrine et histoire. Paris. ViRELLA I BLODA, J. (1981): «Les pintures murals de Sant Valenti de Les Cabanyes", Amics de l'Art Romànic, 11: 108-110.

VorÁgine, S. (1982): La leyenda dorada. Madrid.

YARZA LuACES, J. (1980): "Diablo e infierno en la Miniatura de los Beatos», Simposio para el estudio de los códices del "Comentario al Apocalipsis" de Beato de Liébana. Madrid, I: 231-255.

- (1987): Formas artisticas de lo imaginario. Barcelona.

Xarrie I RoVIRA, J. M. (1981): "Primeres anotacions sobre les pintures de Sant Valenti de Les Cabanyes", Quaderns d'Estudis Medievals, 5: 318-320. 
